
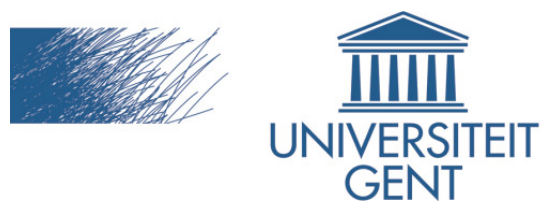

biblio.ugent.be

The UGent Institutional Repository is the electronic archiving and dissemination platform for all UGent research publications. Ghent University has implemented a mandate stipulating that all academic publications of UGent researchers should be deposited and archived in this repository. Except for items where current copyright restrictions apply, these papers are available in Open Access.

This item is the archived peer-reviewed author-version of:

A century of tree line changes in sub-Arctic Sweden shows local and regional variability and only a minor influence of 20th century climate warming

Van Bogaert, R.; Haneca, K.; Hoogesteger, J.; Jonasson, C.; De Dapper, M.; Callaghan, T.V.

In: Journal of Biogeography, 38 (5), 907-921, 2011.

doi: 10.1111/j.1365-2699.2010.02453.x

To refer to or to cite this work, please use the citation to the published version:

Van Bogaert, R.; Haneca, K.; Hoogesteger, J.; Jonasson, C.; De Dapper, M.; Callaghan, T.V. (2011). A century of tree line changes in sub-Arctic Sweden shows local and regional variability and only a minor influence of 20th century climate warming. Journal of Biogeography 38 (5), 907-921. doi: 10.1111/j.1365-2699.2010.02453.x 


\section{A century of tree line changes in sub-Arctic Sweden shows local and regional variability and only a minor influence of $20^{\text {th }}$ century climate warming}

Rik Van Bogaert ${ }^{1,2 *}$, Kristof Haneca ${ }^{3}$, Jan Hoogesteger ${ }^{4}$, Christer Jonasson ${ }^{5,6}$, Morgan De Dapper $^{2}$ and Terry V Callaghan ${ }^{5,7}$

${ }^{1}$ Flanders Research Foundation (FWO); Egmontstraat 5, B-1000 Brussels, Belgium

${ }^{2}$ Department of Geography, Ghent University, Krijgslaan 281 S8, B-9000 Ghent, Belgium

${ }^{3}$ Flemish Heritage Institute, Koning Albert II-laan 19 bus 5, B-1210 Brussels, Belgium, formerly Laboratory of Wood Technology, Ghent University Coupure Links 653, 9000 Ghent, Belgium

${ }^{4}$ Department of Forest Sciences, University of Helsinki, PO Box 27, FI-00014 Helsinki, Finland

5 Abisko Scientific Research Station, Royal Swedish Academy of Sciences, SE-98107 Abisko, Sweden

${ }^{6}$ Department of Physical Geography, Uppsala University, S-75122 Uppsala, Sweden

${ }^{7}$ Department of Animal and Plant Sciences, University of Sheffield, Western Bank, Sheffield S10 2TN, UK

*Corresponding author: Address: Yzerhand 85, B-9120 Beveren, Belgium. rikvanbogaert@gmail.com

Running head: Twentieth century tree line changes in Swedish sub-Arctic 


\section{Abstract}

2 Models project that climate warming will cause the treeline to move to higher

3 elevations in alpine areas and more northerly latitudes in Arctic environments. We

4 aimed to document changes or stability of the treeline in a sub-Arctic model area at

5 different temporal and spatial scales, and particularly to clarify the ambiguity that

6 currently exists about treeline dynamics and their causes. The study was conducted in

7 the Torneträsk area in northern Sweden where climate warmed by $2.5{ }^{\circ} \mathrm{C}$ between

81913 and 2006. Mountain birch (Betula pubescens ssp. czerepanovii) sets the alpine

9 treeline. We used repeat photography, dendrochronological analysis, field

10 observations along elevational transects and historical documents to study treeline

11 dynamics. Since 1912, only four out of eight treeline sites had advanced: on average

12 the treeline had shifted $24 \mathrm{~m}$ upslope $\left(+0.2 \mathrm{~m} \mathrm{year}^{-1}\right.$ assuming linear shifts).

13 Maximum treeline advance was $+145 \mathrm{~m}\left(+1.5 \mathrm{~m} \mathrm{year}^{-1}\right.$ in elevation and $+2.7 \mathrm{~m}_{\text {year }}{ }^{-1}$

14 in actual distance), whereas maximum retreat was $120 \mathrm{~m}$ downslope. Counter-

15 intuitively, treeline advance was most pronounced during the cooler late 1960s and

16 1970s. Tree establishment and treeline advance were significantly correlated with

17 periods of low reindeer (Rangifer tarandus) population numbers. A decreased

18 anthropozoogenic impact since the early $20^{\text {th }}$ century was found to be the main factor

19 shaping the current treeline ecotone and its dynamics. In addition, episodic

20 disturbances by moth outbreaks and geomorphological processes resulted in descent

21 and long-term stability of the treeline position, respectively. In contrast to what is

22 generally stated in the literature, this study shows that in a period of climate warming,

23 disturbance may not only determine when treeline advance will occur but if treeline

24 advance will occur at all. In the case of non-climatic climax treelines, such as those in

25 our study area, both climate-driven model projections of future treeline positions and 
26 the use of the treeline position for bioclimatic monitoring should be used with caution.

27

28

29

30

31

32

33

34

35

36

37

38

39

40

41

42 43

44

45

46

Key words: climate warming, dendrochronology, herbivory, human impact, mountain birch, reindeer, sub-Arctic, Sweden, tree line, tree line causes

2

3

34

35

36

37

38

39

40

\section{1} 42 


\section{Introduction}

Mean annual temperatures have risen globally over the past century, with the most pronounced and rapid changes at high elevations and latitudes (ACIA, 2005). As the location of elevational and polar treelines is mainly caused by heat deficiency, in the Northern Hemisphere climate warming is expected to cause treelines to advance to higher elevations and more northerly latitudes (Harsch et al., 2009). Indeed, modern evidence for such relocations exists and these have been explicitly or implicitly related to recent climate warming (Shiyatov et al., 2007; Kullman and Öberg, 2009). However, in many circumpolar and high-elevational areas the position of the treeline has not changed (Masek, 2001; Holtmeier et al., 2003; Payette, 2007; Van Bogaert et al., 2007) or has even retreated (Vlassova, 2002; Dalen and Hofgaard, 2005; Kullman, 2005; Cherosov et al., 2010).

Treeline heterogeneity increases from global to regional, to landscape and to local scales of analysis (Callaghan et al., 2002). Moreover, the factors controlling the position and structure of the treeline are highly scale-dependent and vary from place to place (Sveinbjörnsson et al., 2002). Individual trees and the forest system may respond differently to change; warming may increase tree growth, while at the same time seedling survival may be reduced because of water stress brought about by greater evapotranspiration and drying of the uppermost soil. Furthermore, the timescale of a study influences outcomes because it determines the processes and responses that can be studied. There are short-term responses (defined as a year or less and reflected in individual tree growth), medium-term responses (some years to a few decades and reflected in changing survival rates of seedlings and altered tree physiognomy) and long-term responses (several decades to centuries and reflected in a general treeline advance or retreat) (Holtmeier and Broll, 2005). 
Both experimental and field studies have shown that climate warming might not be

the only mechanism leading to recently observed northward and upward movement of vegetation. Changes in disturbance regimes (Holtmeier and Broll, 2010), land use (Hofgaard, 1997), plant-plant interactions (Van Bogaert et al., 2009) and herbivory (Hoogesteger and Karlsson, 1992; Speed et al., 2010; Van Bogaert et al., 2010) may easily override the effect of increasing mean annual temperatures.

On a global scale, heat deficiency may be the dominant factor controlling treeline dynamics, but regional studies have shown that treeline position rarely changes in parallel with the shift of any isotherm (Holtmeier and Broll, 2007). At present, one of the most important gaps and uncertainties in treeline research appears on intermediate (10-10,000 km²) spatial scales (Holtmeier and Broll, 2007; Kullman and Öberg, 2009) at which feedbacks to the climate system are significant (Harding et al., 2002), yet studies on the causes of treeline dynamics that also consider site history are very rare (Payette et al., 2002).

The main goal of this paper was to identify and explain recent changes in the position and structure of this vegetation boundary. By confronting long-term climatic and environmental records with new dendrochronological measurements, field observations and analysis of repeat photography, we expected to provide new insights into the driving forces behind current treeline dynamics in northern regions. We focused on a Swedish sub-Arctic study area for which multiple previous treeline studies exist. However, these studies presented contradictory results in terms of both the directions and causes of treeline shifts (Table 1). Furthermore, the suggested causal mechanisms behind reported treeline shifts were not supported by convincing evidence. This study differs from previous ones by providing ample evidence of recent treeline dynamics and their causal mechanisms. Here, we focused on different 
97 spatial scales, ranging from an individual mountain $\left(c .20 \mathrm{~km}^{2}\right)$ to an entire landscape

98 area $\left(\right.$ c. $\left.1000 \mathrm{~km}^{2}\right)$, and different temporal scales, ranging from a 30-year to a 100 -

99 year time period.

100

101

102

103

104

105

106

107

108

109

110

111

112

113

114

115

116

117

118

119

120

121 
The Torneträsk area is located at the eastern fringe of the Scandes Mountains in sub-Arctic Sweden $\left(68^{\circ} 25^{\prime} \mathrm{N}, 1^{\circ} 00^{\prime}\right.$ E) (Fig. 1). The mean annual temperature for Abisko (388 m a.s.l.), located at the south-western end of Lake Torneträsk (Fig. 1), is $-1.0{ }^{\circ} \mathrm{C}$ and mean annual precipitation amounts to $310 \mathrm{~mm}$ for the normal period 1961-90 (Alexandersson et al., 1991). However, climate has recently changed: mean annual temperature and precipitation increased from $-1.2{ }^{\circ} \mathrm{C}$ and $301 \mathrm{~mm}$, respectively, during the first instrumental decade (1913-22) to $+0.6{ }^{\circ} \mathrm{C}$ and $342 \mathrm{~mm}$

132 for the 10-year period 2000-09 (Abisko Scientific Research Station meteorological records 1913-2009). Moreover, statistically smoothed trends showed a $2.5{ }^{\circ} \mathrm{C}$ increase in temperature over the period 1913-2006 (Callaghan et al., 2010). Lake Torneträsk is surrounded by $1200 \mathrm{~km}^{2}$ of subalpine forests dominated by mountain birch (Betula pubescens Ehrh. ssp. czerepanovii (Orlova) Hämet-Ahti), the species that sets the treeline in Fennoscandia. The position of the alpine treeline varies around $700 \mathrm{~m}$ a.s.1. (Dalen and Hofgaard, 2005). Local variability in precipitation, topography, geology and land-use history is substantial (Hofgaard, 1999). Polycormic (multi-stemmed) types of birch forest are found in dry areas with poor soils, whereas monocormic (single-stemmed) birch forests can be found in areas with a deeper snow cover and a more calcareous soil (Sonesson and Hoogesteger, 1983). The dominant agents of disturbance to the birch forest are the more or less cyclic pest outbreaks of the autumnal moth (Epirrita autumnata Bkh.) and the winter moth (Operophtera brumata L.) (Tenow, 1972). At the treeline, disturbance by reindeer (Rangifer tarandus L.) may be significant (Cairns and Moen, 2004). 
149 In the present paper the term 'treeline' refers to the transition zone extending from the upper limit of the closed subalpine forest to the uppermost birch individual. In repeat photography analysis, we used the lower boundary of this ecotone as a main reference as it is more distinct than the upper boundary. This boundary was set to $30 \%$ tree-cover in a convention used by most other treeline studies (Rees et al., 2002).

154 Time series of photographs were scanned at identical resolution, so that individual 155 pixels could be compared. A pixel was classified as forested or non-forested. The $15630 \%$ tree-cover isoline was statistically plotted using ARCGIS SPATIAL ANALYST 9.2 157 (ESRI, Redlands, CA, USA) (Fig. 2).

158 The boundary line was visited in situ at locations where the $30 \%$ tree-cover isoline 159 crossed an easily identifiable landmark such as a big boulder (Fig. 2). Field 160 measurements showed that the individual trees at the treeline detectable on the 161 photographs had a mean canopy size of $3.5 \mathrm{~m}$ diameter, implying that a $30 \%$ tree162 cover corresponded to a distance interval of $2.2 \mathrm{~m}$ in any direction between the 163 canopy boundaries of different individuals trees. In the field we could now delimit 164 both the upper and lower boundary of the treeline ecotone. Note that the outcome of 165 this study did not depend on the definition setting. A $10 \%$ tree-cover analysis $(7.0 \mathrm{~m}$ 166 between different tree canopy boundaries) produced similar results. Repeat photographic analysis

169 Seven ground photographs taken between 1912 and 1952 from different mountain 170 slopes in the Torneträsk area were successfully repeated (Fig. 1). Prominent 171 landmarks were found in the direct vicinity of the historical treeline (Fig. 2). The 
172

173

174

175

176

177

178

179

180

181

182

183

184

185

186

187

188

189

190

191

192

194

195

196

actual shift in elevational position of the treeline could then be estimated by comparing the old and recent photographs and by recording the elevational difference between the landmark and the present treeline position with a calibrated aneroid altimeter in the field.

Furthermore, repeat aerial photographs from the period 1959-2000 were studied to quantify recent elevational shifts in the boundaries of the treeline ecotone of Mount Nuolja $\left(\mathrm{M}_{\mathrm{S} 3}\right.$ in Fig. 1). The images were scanned at 1600 dots per inch (d.p.i.) implying a resolution of $0.3 \mathrm{~m}$ and were then georeferenced and rectified in the program ORBIT GIS 4.4 (Eurotronics, 2009, Lokeren, Belgium). Maximal geometric distortion between the two photographs amounted to $5 \mathrm{~m}$. To study the driving forces behind treeline dynamics, we looked for contrasting results from the analyses of the aerial photographs. Two areas were selected for further analysis in the field: (1) an area on the east slope of Mount Nuolja characterized by a significant upslope shift of the treeline, and (2) an area on the south slope with no significant change in the position of the treeline.

\section{Repeat transect analysis and field measurements}

To study the causal mechanisms and timing of treeline advance, tree sampling and field measurements were carried out at five sites in the wider Torneträsk area in 2006. We sampled treeline individuals at the two contrasting sites of Mount Nuolja and at the three Sonesson and Hoogesteger transect sites N1, N2 and S1 (Fig. 1). In 1977, these transect sites were randomly selected in treeline areas that differed in climate (dry versus wet), soil (calcareous rich versus poor) and tree growth form (monoversus polycormic birch forest) (Sonesson and Hoogesteger, 1983). In 2006, we established nine transects through the birch forest: three at sites N1, N2 and S1 
corresponding to the original transects of Sonesson and Hoogesteger, and six on

198 Mount Nuolja (three on the east and three on the south slope). The Sonesson and

199 Hoogesteger transects were $c .1200 \mathrm{~m}$ long and crossed several contours running from

200 the lake level (341 $\mathrm{m}$ a.s.1.) up to the alpine area (c. $700 \mathrm{~m}$ a.s.1.). At the upper end of 201 these transects, 40 treeline birches were randomly sampled over a width of $500 \mathrm{~m}$. For 202 Mount Nuolja, a transect set-up of higher resolution was designed to identify the 203 causes of the contrasting treeline dynamics that were found by repeat photographic 204 analysis. The transects were $200 \mathrm{~m}$ long and ran along different contours equally 205 spread over the treeline ecotone (see Appendix 1). All six transects contained seven 206 plots measuring $10 \times 10 \mathrm{~m}$, in which all birch individuals were sampled. The birches 207 were cut off at the root collar (individuals $<2 \mathrm{~m}$ ) or cored as low as possible 208 (individuals $>2 \mathrm{~m}$ ) with an increment corer according standard methods (Fritts, 1976).

209 Twenty-five monocormic erect birch individuals were cored $40 \mathrm{~m}$ downslope of all 210 five treeline sites to serve as a reference for the treeline samples. However, because 211 ring growth of these reference individuals may also have been affected by ubiquitous 212 moth herbivory, 30 non-browsed pine (Pinus sylvestris L.) individuals were sampled 213 in the Abisko area to construct a birch-minus-pine ring-width chronology that serves 214 as a reference for moth herbivory on birch (Eckstein et al., 1991; Van Bogaert et al., 215 2009). (For more methodological detail, see Van Bogaert et al., 2009.)

216 To study the mechanisms behind treeline shifts, the following variables were 217 recorded for all sampled birch individuals: tree height, stem diameter at breast height 218 (130 cm; DBH), growth form (mono- or polycormic), herbivory damage, elevation (m 219 a.s.1.), inclination, aspect and snow depth. Herbivory damage was classified visually 220 as browsed or not browsed, but also statistically by constructing a birch-minus-pine 221 ring-width chronology and anatomically by studying features of wood anatomy 
(Appendix 2). The mean height limit of the epiphytic lichen Melanelia olivacea (L.)

223 Essl. on adult birch stems was used as a proxy for mean snow depth (Sonesson et al.,

224 1994). All measurements and dendrochronological analyses have been made with

225 identical methods applied in the original study by Sonesson and Hoogesteger (1983)

226 and with field assistance by one of the original researchers.

227 Altogether, we studied changes in the elevational position of the treeline ecotone 228 for 10 sites spread over the Torneträsk area (Mount Nuolja $\mathrm{M}_{\mathrm{S} 3}$ had two sites; Fig. 1).

229 In total, 678 tree cores and 188 stem discs of mountain birch and 30 tree cores of pine 230 were analysed to study site history. (For a detailed description of the 231 dendrochronological analysis, see Appendix 2.) The samples were also used to cross232 reference with the estimated treeline dynamics that we obtained from repeat 233 photography and repeat transect analysis.

\section{Analysis of tree establishment}

236 The year of tree ( $>2 \mathrm{~m}$ ) establishment was determined by exact tree-ring dating of 237 the innermost growth ring surrounding the pith. However, the year of establishment is 238 hard to determine when the individual is not cored at the stem-root intersection or the 239 pith is not perfectly hit. Therefore, estimated establishment data were derived from 240 the tree cores after grouping them into 10-year age classes. Tree cores of treeline 241 birches with rotten pith (13\%) or with a substantial number of rings missing due to 242 failure to hit the pith $(22 \%)$ were omitted from this analysis. An annual recruitment 243 analysis was made for the saplings $(<2 \mathrm{~m})$ that were cut off at the root collar $(n=188)$ 244 to allow for a more accurate determination of the year of establishment. The presumed 245 annual number of birch recruits was correlated with climatic and biotic factors using 246 Spearman's rank correlation coefficients $\left(r_{\mathrm{s}}\right)$. 
Historical anthropozoogenic impact

249 Emanuelsson (1987) produced a map with the locations of the traditional reindeer 250 migration routes and the reindeer herder camps near the treeline (Appendix 3). These 251 points of relatively intense previous human impact were located in the field and 252 distances to our study sites were recorded by a GARMIN GPSMAP60CSX device.

Long-term records as validation

256

The Torneträsk area has an exceptionally long-term record of climatic and other environmental data offering a powerful instrument for validation of measurements (Callaghan et al., 2010). Daily temperature and precipitation measurements are available since 1913 (Callaghan et al., 2010), human impact has been described in detail since 1600 (Emanuelsson, 1987), reindeer population numbers since 1750 (Emanuelsson, 1987) and moth outbreaks on birch have been reported since 1862 (Tenow, 1972).

\section{Statistical analyses}

Regression analyses with forward selection were used to test which of the environmental and anthropogenic variables best explained the elevational shifts of the treeline ecotone. The sign of relationships and relative importance of the variables that corresponded to elevational shifts in the treeline position were studied using Pearson correlation coefficients. For further information on the technical details of the correlation of treeline dynamics and compass direction see Dalen and Hofgaard (2005). All statistical analyses were conducted in the program SPSS v. 15.0 (SPSS INC., 2006, Chicago, IL, USA). 


\section{Results}

Treeline dynamics

275 At the scale of an individual mountain, analysis of repeat aerial photographs of 276 Mount Nuolja for the period 1959-2000 showed that the upper limit of the closed 277 forest, representing the lower boundary of the treeline ecotone, had increased in 278 elevation by $25 \mathrm{~m}$ (rate of $+0.6 \mathrm{~m}$ year $^{-1}$ assuming linear advances). However, site 279 variability was high: on the eastfacing slope an area was found where this boundary 280 had increased in elevation by $45 \mathrm{~m}\left(+1.1 \mathrm{~m} \mathrm{year}^{-1}\right)$ as a result of a dramatic 281 densification of the uppermost tree patches (Fig. 3). In contrast, on the south-facing 282 slope a significant area was found where the boundary had remained stationary (Fig. 283 3). These trends were persistent over a longer period (1912-2009). On the east-facing 284 site, repeat landscape photography showed that the treeline ecotone had advanced 60 $285 \mathrm{~m}$ in elevation since $1912\left(+0.6 \mathrm{~m} \mathrm{year}^{-1}\right.$; Table 2$)$. On the south-facing site, 286 dendrochronological analysis showed long-term immobility: at the upper and lower 287 boundary of the treeline ecotone $8 \%$ and $28 \%$, respectively, of the treeline birches had 288 established before 1900 (Table 3).

289 At the landscape scale, repeat photography and dendrochronological analysis 290 showed that the lower boundary of the treeline ecotone in the Torneträsk area had on 291 average advanced $24 \mathrm{~m}$ in elevation over the period 1912-2009 (+0.2 $\left.\mathrm{m} \mathrm{year}^{-1}\right)\left(\right.$ Table $^{2}$ 292 2). However, at this scale also, spatial variability was high: at four out of the eight 293 remaining treeline sites the treeline had moved upslope, at three others it had 294 remained stationary, and at one site the treeline had significantly descended (Table 2). 295 The treeline ecotone of site S4, located along the reindeer migration route 296 (Appendix 3), had shifted $145 \mathrm{~m}$ upslope $\left(+1.5 \mathrm{~m} \mathrm{year}^{-1}\right)$ or $260 \mathrm{~m}$ in actual distance 
297 (+2.7 $\mathrm{m} \mathrm{year}^{-1}$ ) over the period 1912-2009 (Fig. 2, Table 2). Moreover, significant

298 forest densification was observed at the treeline and in the lowland (Fig. 2). In sharp

299 contrast, the continuous treeline boundary of site N1 was $120 \mathrm{~m}$ lower in elevation in

3002009 compared with the years 1912 and 1952 (Fig. 4, Table 2). The retreat was

301 caused by a severe outbreak of the winter moth (O. brumata) in 1964-65 and

302 extended over a distance of more than $10 \mathrm{~km}$ (Fig. 4). Although in 1977 two young

303 birches were documented at site N1 in the recently created forest gap, these

304 individuals had perished by 2006 (Fig. 5). At treeline site N2 and the area up to $7 \mathrm{~km}$

305 eastwards of this site, both the lower and upper boundaries of the treeline ecotone had

306 remained stationary since at least 1912 (Table 3). The uppermost birch trees (>2 m)

307 were between 110 and 258 years old with little or no recruitment of new trees $(>2 \mathrm{~m})$

308 in the last 100 years (Fig. 5). Most of the smaller birches $(\mathrm{DBH}<2.5 \mathrm{~cm})$ recorded at

309 site N2 in 1977 had perished by 2006 (Fig. 5). At site S1 on the southern side of Lake

310 Torneträsk, potential treeline advance was seen (Fig. 5). In contrast, at sites N4 and

311 S5, which were characterized by slope angles $>35$, immobility of the position of the

312 treeline was documented for the past 60 to 100 years (Fig. 6).

313

\section{Presumed drivers of treeline dynamics}

315 Sites that were located in the vicinity of previous human activity showed a 316 pronounced advance of the treeline. This was indicated by the significant negative 317 correlation found between the elevational shift of the treeline and the distance to 318 previous campsites of reindeer herders or the railway that was constructed in 1898$3191902(r=-0.46 ; P=0.04$; Table 2, Appendix 3). Previous anthropogenic impact 320 explained $35 \%$ of the variance in documented treeline dynamics (measured by $R^{2}$ ) 321 since 1912. When adding snow depth to the regression, $R^{2}$ increased to $59 \%$ (Table 

documented shifts of the position of the treeline $(r=0.24 ; P=0.48$; Table 2$)$. However, browsing damage to both seedlings and trees ( $>2 \mathrm{~m}$ ) identified by dendrochronological analysis showed a significant correlation with documented treeline shifts $(r=-0.82 ; P=0.03$; Table 2 , values in brackets). Adding this parameter to the regression increased $R^{2}$ to $68 \%$ for these five sites. Polycormicity of treeline birches was positively correlated with advance of the treeline (Table 2). In contrast, aspect and inclination showed no overall correlation with recorded treeline shifts since 1912.

Annual recruitment of birch saplings $(<2 \mathrm{~m})$ at the treeline of Mount Nuolja was not correlated with summer (June-August) or winter (December-February) temperature for the period of measurement 1964-2006 $\left(r_{\mathrm{s}}=0.14, P=0.74\right.$ and $r_{\mathrm{s}}=-$ $0.08, P=0.88$, respectively) (Fig. 7). Neither was annual birch recruitment correlated with summer or winter precipitation $\left(r_{\mathrm{s}}=0.12, P=0.66\right.$ and $r_{\mathrm{s}}=-0.14, P=0.76$, respectively). Also, no positive correlation $\left(r_{\mathrm{s}}=-0.21, P=0.20\right)$ was found between summer temperature and tree ( $>2 \mathrm{~m}$ ) establishment for the long-term period 18002000 (Fig. 8). In contrast, disturbance at the treeline, expressed by the negative birchtreeline-minus-pinesubalpine and birchtreeline-minusbirchsubalpine ring-width 340 indices, was positively correlated with annual birch $(<2 \mathrm{~m})$ recruitment $\left(r_{\mathrm{s}}=0.54, P=\right.$ 3410.06 and $r_{\mathrm{s}}=0.47, P=0.10$ respectively) (Fig. 7). Furthermore, a significant negative 342 correlation was found between tree $(>2 \mathrm{~m})$ establishment at the treeline and reindeer 343 population numbers for the period 1800-2000 $\left(r_{\mathrm{s}}=-0.69 ; P=0.03\right)$. Comparatively 344 low tree establishment numbers were recorded for the warmer 1850s and 1920-30s, 345 when reindeer population numbers were high, whereas high tree establishment 346 numbers were found for the cool late 19th century and particularly during the cooler 
late 1960s and 1970s when reindeer population numbers were low (Fig. 8). Even when saplings $(<2 \mathrm{~m})$ were included in the analysis, birch establishment at the treeline was highest during the late 1960s and 1970s.

$$
\text { Nevertheless, climate highly determined birch growth at the treeline. Exceptionally }
$$
cool summers caused significantly $(P<0.05)$ reduced radial growth for 1 year in the subalpine birches, but for 2 years in the birches at the treeline (e.g. 1900-01 and 1975-76, Table 4).

The main biotic disturbance events during the period 1800-2006 that significantly $(P<0.05)$ reduced radial growth in the treeline individuals were, in order of importance, reindeer browsing and moth herbivory (Table 4). Reindeer browsing damage showed local variability, both in timing and intensity. For example, greater damage was seen on the south slope of Mount Nuolja than on the east slope (Table 4). However, if reindeer population numbers were high, browsing damage was ubiquitous on all sites studied: for the years 1863, 1911, 1929, 1979 and 1985 the treeline birches showed browsing scars together with significant growth reductions (Table 4). The most severe and ubiquitous damage in the $20^{\text {th }}$ century caused by browsing was found in the year 1929, when reindeer population numbers reached an absolute peak (Fig. 8). During that year more than $50 \%$ of the treeline birches in the Torneträsk area showed a significant growth reduction (Table 4).

Invertebrate herbivory also affected the treeline. During the summers of 1902-03, 1964-65, and to a lesser extent in 1955 and 1994, moth herbivory caused significant growth reductions and, in 1964-65 large-scale mortality (Fig. 4) in the birches constituting the treeline ecotone (Table 4). Local variability in the impact of disturbance was again substantial (Table 4). 


\section{Discussion}

\section{Trends and presumed causes of treeline dynamics}

376

377

378
This study aimed to document changes or stability in the treeline ecotone in the Torneträsk area at different temporal and spatial scales, and particularly to clarify the ambiguity that currently exists about treeline dynamics and the driving processes behind them (Table 1).

In contrast to one of the most widely held expectations of vegetation responses to warming, i.e. that Arctic treelines will move northwards and elevational treelines upslope (Harsch et al., 2009), this study documented highly varying treeline dynamics for the Torneträsk area in sub-Arctic Sweden during a period of multi-decadal climate warming (Callaghan et al., 2010). Contrasting treeline dynamics were recorded at spatial scales ranging from an individual mountain to an entire landscape and at temporal scales ranging from three decades to more than a century (Figs 3 and 5, Table 2). This is surprising because temperature and precipitation, the climatic parameters generally accepted to limit recruitment and growth at the mountain birch treeline (Kullman and Öberg, 2009), both significantly increased since 1913 (see 'Study area').

Moreover, dendrochronological analysis indicated that treeline advance in the past two centuries was most pronounced during the cooler late 1960s and 1970s (Fig. 8), contradicting the interpretations of previous studies in the area (Table 1). During this period, reindeer population numbers in the Torneträsk area reached a record low following some severe winters. By the late 1960s the total herd had become three times smaller than in the period 1850-60 when all reindeer were gathered around the 
treeline by the nomadic herders (Fig. 8; Emanuelsson, 1987). Although reindeer have

398 always been part of the birch ecosystem, their impact on the vegetation should be

399 evaluated in terms of population densities (Helle, 2001). Fenced pastures near the

400 treeline in the $19^{\text {th }}$ and early $20^{\text {th }}$ centuries resulted in higher reindeer population

401 densities in the treeline ecotone than in both earlier and more recent times

402 (Emanuelsson, 1987). Dendrochronological analysis for the five transect sites N1, N2,

$403 \mathrm{~S} 1, \mathrm{~S} 3_{\mathrm{E}}$ and $\mathrm{S} 3_{\mathrm{S}}$ showed that the impact of reindeer browsing at the treeline gradually

404 decreased after the 1930s (Table 4). From the 1920s onwards, the campsites and

405 pastures have been gradually abandoned, synchronously with most other heavily

406 grazed out-farms in Fennoscandia (Bryn and Daugstad, 2001; Lundh, 2001).

407 A similar process of reduced human impact was identified at site S2. Repeat 408 landscape photography and dendrochronological analysis showed a remarkable 409 densification and an upslope shift by $50 \mathrm{~m}$ of the lower boundary of the treeline 410 ecotone for the period 1912-2009 (Table 2). However, historical reports documented 411 the local clearance of the birch forest at this site between 1898 and 1902, thereby 412 lowering the treeline ecotone by $70 \mathrm{~m}$ (Emanuelsson, 1987). Extending the period by 41315 years would result in a net balance of a $20 \mathrm{~m}$ descent of the treeline for the period 414 1897-2009. This shows the importance of the temporal scale in treeline research and 415 suggests caution with far-reaching conclusions based on findings such as apparent 416 correlations between temperature and treeline advance obtained from short-term 417 studies.

418 Reduced anthropozoogenic disturbance (Ellenberg, 1988) compared with the early $41920^{\text {th }}$ century best explained the varying treeline shifts recorded in our study area 420 (Table 2). We confirmed the hypothesis of Emanuelsson (1987) and Cairns and Moen 421 (2004) that the impacts of humans and semidomesticated herbivores have 
422

423

significantly determined the elevational shifts of the treeline boundary (Table 1). Distinguishing human impact from natural factors is, however, one of the most difficult tasks in treeline research (Ellenberg, 1988; Hofgaard, 1997). Only accurate historical reports of the anthropozoogenic impact on northern vegetation make a proper evaluation of this factor possible. Unfortunately, this information is often not available (Moen et al., 2008) and is a major weakness in studies dealing with range migrations of plant species. The Torneträsk area has a long history of human occupation, but human impact was presumably not higher than in other areas of northern Eurasia (Von Middendorf, 1864; Veijola, 1998; Hofgaard, 1999; Lundh, 2001; Vlassova, 2002). The major difference from other regions is rather that its anthropozoogenic impact has been well documented since c. 1600 (Emanuelsson, 1987).

In addition to reindeer grazing, the mountain birch treeline also suffers from episodic outbreaks of the autumnal and winter moth (Kallio and Lehtonen, 1973). Several studies have shown that the lack of recovery of forests defoliated by moths is the product of an interaction between damage due to moth outbreaks and reindeer grazing (Kallio and Lehtonen, 1973; Helle, 2001; Tenow et al., 2005). In the mid 1960s, caterpillars of the autumnal moth defoliated the birch treeline ecotone in northern Finland over an area of c. $5000 \mathrm{~km}^{2}$, of which $1200 \mathrm{~km}^{2}$ of birch forest did not recover (Seppälä and Rastas, 1980). Exclosure experiments showed that reindeer grazing of birch seedlings was the cause of the lack of forest recovery (Lehtonen and Heikkinen, 1995). This interaction between moth and reindeer herbivory forms the greatest threat to the mountain birch forest, and devastated areas may remain treeless for decades to centuries irrespective of prevailing climatic conditions (Seppälä and Rastas, 1980). At treeline sites N1 and N2 we documented this process. The lack of 
recent tree $(>2 \mathrm{~m})$ establishment and the browsing scars documented in the tree rings

448 indicated that, in addition to moth herbivory, reindeer browsing is still a controlling

449 factor at these sites (Fig. 5, Table 4). This example further stresses the importance of

450 disturbance in regulating recruitment and mortality at the treeline and masking or 451 even nullifying any beneficial effects of recent climate warming on tree recruitment 452 and treeline shifts (see Fig. 7).

\section{Other factors affecting treeline dynamics}

A multitude of environmental conditions affect tree establishment and survival and these factors may differ in space and time (Sveinbjörnsson et al., 2002). Besides anthropozoogenic impacts, snow depth significantly increased the proportion of explained variance in documented treeline dynamics $\left(R^{2}\right.$ increased from 0.35 to 0.59 ; Table 2). The importance of an ample snow cover for mountain birch, providing insulation in winter and moisture in spring, has been elucidated in previous treeline studies (Dalen and Hofgaard, 2005; Kullman and Öberg, 2009). Nevertheless, winter precipitation was not correlated with tree establishment at the treeline, suggesting that local snow distribution is a more complex factor than just the sum of amounts of winter precipitation (Holtmeier and Broll, 2010).

In contrast to other studies (Danby and Hik, 2007; Kullman and Öberg, 2009), slope aspect and inclination were not correlated with elevational shifts of the treeline ecotone. Possibly, local site conditions and various historical disturbances were of greater importance than relative solar radiation and regional wind exposure. The lack of correlation between inclination and documented treeline shifts resulted from the fact that both flat and very steep slopes experienced immobility of the treeline (Table 2), possibly because of high wind exposure and geomorphological activity, 
472

473

474

475

476

477

478

479

480

482

483

484

485

486

487

respectively (Holtmeier and Broll, 2010). Polycormicity of treeline birches was positively correlated with documented elevational shifts of the position of the treeline (Table 2). Polycormic birch forests are less prone to disturbance than monocormic forests as they do not rely on hazardous seedling establishment (Tenow et al., 2005). At the polycormic treeline of Mount Nuolja we recorded high birch recruitment during years with increased disturbance (Fig. 7).

\section{Projecting future treeline dynamics}

The extreme discrepancy that exists between model projections of the treeline position and in situ observations is a world-wide phenomenon (Holtmeier and Broll, 2007; Van Bogaert et al., 2007). In the next 100 years, alpine and polar treelines are projected to shift upslope by 2 to $6 \mathrm{~m}^{-1}$ year $^{-1}$ (Moen et al., 2004) and northwards by 7.4-20 km year ${ }^{-1}$ (Kaplan and New, 2006) if climate warming continues. However, the fastest upslope shifts of treelines recorded during $20^{\text {th }}$ century warming are in the range of 1 to $2 \mathrm{~m} \mathrm{year}^{-1}$ (Shiyatov et al., 2007; Kullman and Öberg, 2009). Moreover, the fastest northward-migrating treeline replaces tundra by taiga at a rate of 3-10 m year $^{-1}$ (Kharuk et al., 2006); i.e. 2000 times slower than model projections. For comparison, the fastest upward and lateral (actual distance) displacements of the treeline in the Torneträsk area were respectively $+1.5 \mathrm{~m} \mathrm{year}^{-1}$ and $+2.7 \mathrm{~m} \mathrm{year}^{-1}$. A global study by Harsch et al. (2009) showed that only 52\% of all 166 global treeline sites had advanced over the past 100 years despite documented amplified climate warming at high-elevation areas and northern latitudes (ACIA, 2005).

Climate scenarios for our study area in northern Fennoscandia project an increase in mean annual temperature of $3.5{ }^{\circ} \mathrm{C}$ by the year 2080 compared to the reference period 1980-2000 (Saelthun and Barkved, 2003) and an upslope shift of the treeline 
by 233-667 $\mathrm{m}$ for the next 100 years (Moen et al., 2004). In such scenarios, mountain

498 birch would be largely replaced by conifer tree species (Wolf et al., 2008a). However,

499 these models almost exclusively operate with positive growth responses, and new

500 findings such as likely increases in birch herbivory in a warming sub-Arctic (Ims et

501 al., 2007; Wolf et al., 2008b) and negative growth responses to increased temperatures

502 (Kirchhefer, 1996) suggest that the modelled treeline advances are unlikely to be fully

503 realized. Indeed,Van Bogaert et al. (2010) showed that not a conifer but deciduous

504 European aspen (Populus tremula L.) recently colonized the birch treeline ecotone in

505 our study area. Moreover, topography, being the only relatively constant factor

506 through time, will prevent an upslope shift of orographically controlled treeline areas

507 (inclination $>35^{\circ}$ ) such as sites N4 and S5 (Fig. 6).

508 In conclusion, in areas where the number of domesticated herbivores has decreased

509 over the past century, rapid vegetation changes and advances in the treeline may be

510 expected. However, in treeline areas controlled by severe disturbance by moth

511 herbivory or slope processes, treeline advance may not occur. In contrast to Harsch et

512 al. (2009) who concluded that the role of disturbance during recent climate warming

513 is restricted to determining when treeline advance will occur, this study shows that

514 disturbance and its after-effects may equally well determine if treeline advance will 515 occur at all. 


\section{SUPPORTING INFORMATION}

Appendix S1 High-resolution transect design for Mount Nuolja. Each transect line had seven plots, numbered from left to right. The spatial intervals refer to actual distances in metres. Abbreviations used: U: Upper transect line; M: Middle transect line; L: Lower transect line.
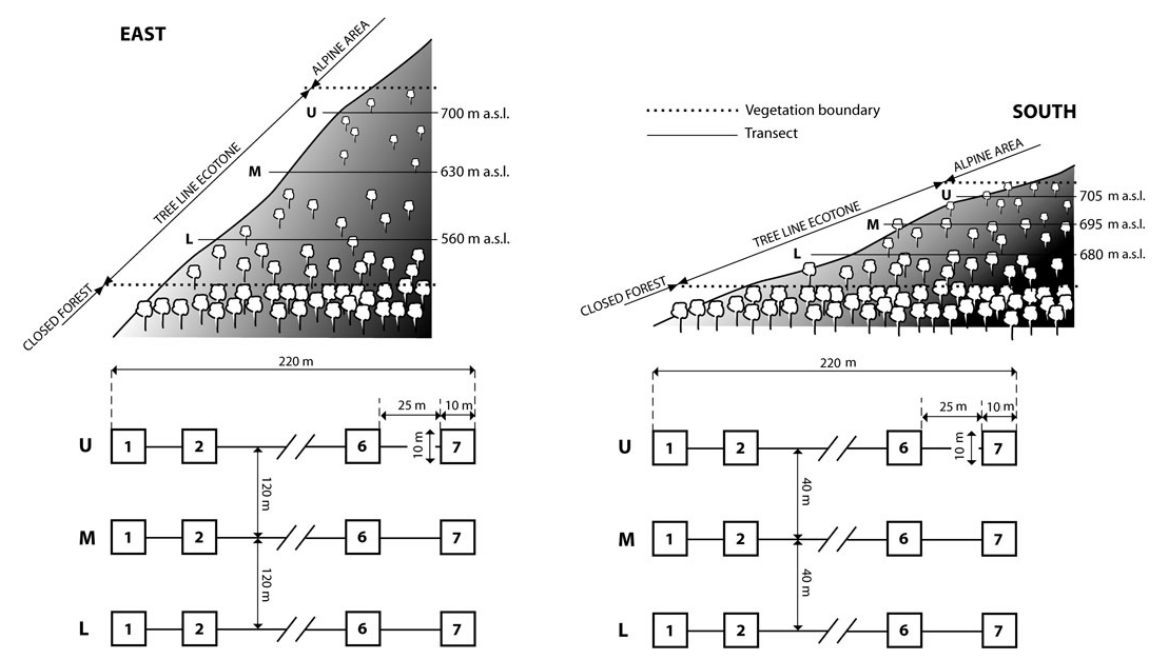
Appendix S2 Dendrochronological analysis.

\section{Tree sampling}

Tree cores were taken as low as possible (at $c .20 \mathrm{~cm}$ stem height), so that the presumed year of establishment could be determined by subsequent tree-ring counting. The mean difference in the number of annual rings counted at the root collar and at $20 \mathrm{~cm}$ stem height of the saplings was added to the number of tree-rings counted on the tree cores to make a better estimate of the year of tree establishment. Cores taken at $20 \mathrm{~cm}$ stem height or higher are more suitable for the identification of disturbance events (Schweingruber, 2007). Stunted and older individuals were also cored at breast height to avoid tension wood and reduce the number of missing rings that are common at lower stem height (Sonesson \& Hoogesteger, 1983).

\section{$\underline{\text { Ring-width chronology construction }}$}

Ring-widths were measured up to $0.01 \mathrm{~mm}$ precision using a LINTAB $^{\mathrm{TM}}$ measuring stage and the dendro software package TSAPWin ${ }^{\text {TM }}$ v. 0.53 (Rinn, 2003, Heidelberg, Germany). Ring-width chronologies were built for the reference birches sampled below the tree line ecotone of the five tree line sites located at Mount Nuolja $\left(\mathrm{S} 3_{\text {East }}\right.$ and $\left.\mathrm{S} 3_{\text {South }}\right)$ and at the Sonesson and Hoogesteger transects (N1, N2, and S1; Fig. 1). These five birch chronologies, in addition to the pine chronology, served as a ring-width reference for the tree line birches. Chronology building was done in TSAPWin $^{\mathrm{TM}}$ using both visual comparisons and well-established statistical parameters. Values of $t_{\mathrm{BP}}$ greater than 4.0 and of GLK\% ('Gleichläufigkeit'; the degree that trees react with a similar growth increase or decrease compared to the previous growing 
season) greater than $65 \%$ were considered significant in analogy with previous studies (Levanič \& Eggertsson, 2008). In this way, missing rings were generally easily identified. Individual ring-width series were standardised in the program ARSTAN (Cook, 1985) using regional curve standardisation (Briffa et al., 1992).

\section{Interpretations of stem cross section anatomy (Fig. S1)}

In addition to a statistical ring-width approach, we performed a meticulous study of the wood anatomical features of the tree line birches. This analysis generally provides more information about the disturbance event than do statistics of differences in ring-widths (Levanič \& Eggertsson, 2008). Frost rings, white rings, browsing scars and callus tissue all point to specific damage patterns (Fig. S1).

Narrow rings can be the result of e.g. a cool summer, reindeer (or other mammal) browsing, or moth herbivory. If only young and small $(<2 \mathrm{~m})$ tree line individuals show a narrow ring in year ' $\mathrm{x}$ ', a cool summer is less likely to be the cause of the growth reduction. In this case reindeer browsing is more likely since the browse height of reach for reindeer is limited to $c .1 .5 \mathrm{~m}$ and will therefore mainly affect saplings (Helle, 2001). This hypothesis may later be confirmed if one or more young individuals are found that show a browsing scar for year ' $x$ ' (Fig. S1c). If only older individuals ( $>60$ years) show a narrow ring for year ' $y$ ', a cool summer is less likely, but defoliation by the autumnal or winter moth, who select for older individuals (Bylund, 1995), is more likely. This hypothesis may later be confirmed if one or more older individuals show a 'white' ring for year ' $y$ ', pointing to a defoliation event by an invertebrate (Schweingruber, 2007) (Fig. S1d).

Reindeer mainly strip off the birch leaves, rather than gnawing on the twigs and 
stems (Haukioja \& Heino, 1974). Therefore, a part of the browsing scars observed in the tree-rings may be attributed to moose, voles, and particularly to mountain hare (Lepidus timidus L.) that also feed on birch, although predominantly in winter (Danell \& Huss-Danell, 1985). However, the most ubiquitous growth reductions accompanied by several small browsing scars were identified for the summer of 1929, the year when reindeer population numbers reached an absolute peak (Fig. 8 and Table 4). Therefore, we assumed throughout the study that the browsing scars documented in the growing season were attributed to reindeer.
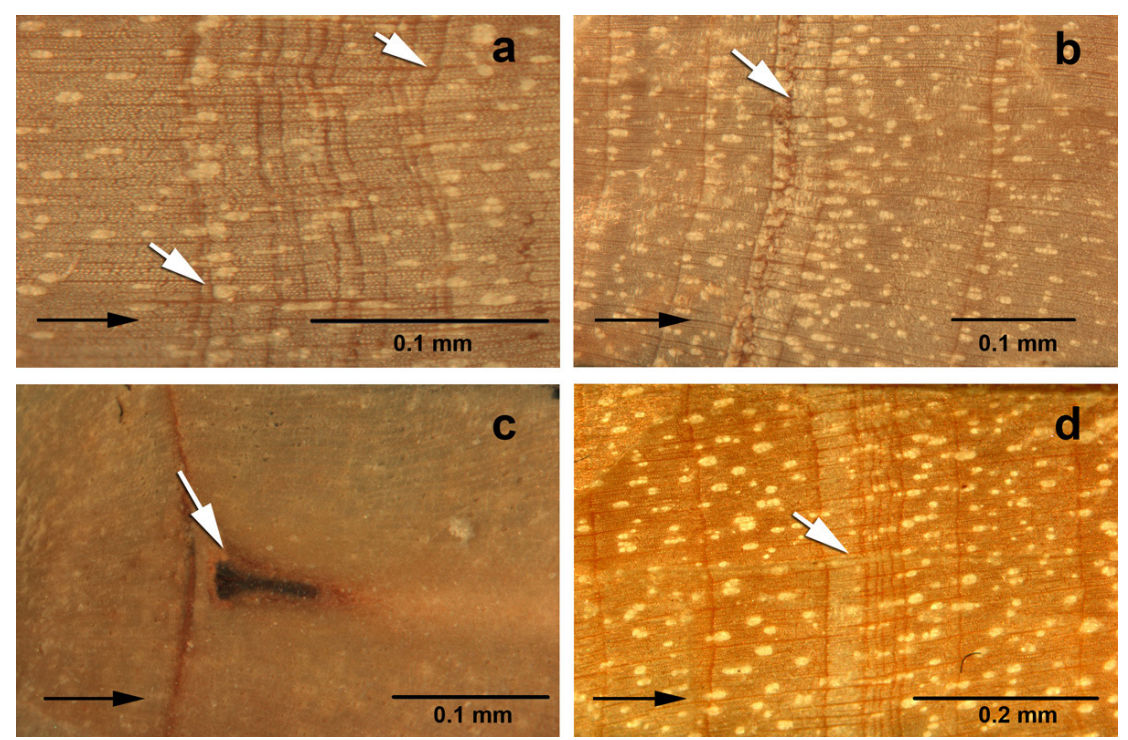

Figure S1 Study of wood anatomical features in mountain birch. The white arrows point to the area of interest, whereas the black arrows show the direction of growth. Birch individuals subjected to biotic or climatic stress regularly show wedging rings (a) that may result in erroneous dating. Pointer years such as the frost ring of 1984 shown in (b) can help in tracing these partly or completely missing rings. A typical frost ring (b) showing damage to the cambium. In June 1984, a 27-day period of 
warm spring weather with minimum temperatures up to $+11.9^{\circ} \mathrm{C}$ was suddenly interrupted by three days of $-1.3{ }^{\circ} \mathrm{C}$, recorded at the Abisko meteorological station located $300 \mathrm{~m}$ below the tree line. A small scar (c) at $110 \mathrm{~cm}$ stem height presumably caused by reindeer browsing in the early summer of 1929. A bright coloured ring followed by four exceptionally narrow rings (d) points to complete tree defoliation by an insect.

\section{$\underline{\text { References }}$}

Briffa, K.R., Jones, P.D., Bartholin, T.S., Eckstein, D., Schweingruber, F.H., Karlén, W., Zetterberg, P. \& Eronen, M. (1992) Fennoscandian summers from AD 500: temperature changes on short and long timescales. Climate Dynamics, $\mathbf{7}$, 111-119.

Bylund, H. (1995) Long-term interactions between the autumnal moth and mountain birch: The role of resources, competitors, natural enemies and weather. $\mathrm{PhD}$ Thesis, Department of Entomology, Swedish University of Agricultural Sciences (SLU), Uppsala.

Cook, E.R. (1985) A time series analysis approach to tree-ring standardization. $\mathrm{PhD}$ Thesis, University of Arizona, Tucson, AZ.

Danell, K. \& Huss-Danell, K. (1985) Feeding by insects and hares on birches earlier affected by moose browsing. Oikos, $\mathbf{4 4}, 75-81$.

Haukioja, E. \& Heino, J. (1974) Birch consumption by reindeer (Rangifer tarandus) in Finnish Lapland. Reports from the Kevo Subarctic Research Station, 11, 2225. 
Helle, T. (2001) Mountain birch forests and reindeer husbandry. Nordic mountain birch ecosystems (ed. by F.E. Wielgolaski), pp. 279-291. UNESCO, Paris and Parthenon, New York.

Levanič, T. \& Eggertsson, O. (2008) Climatic effects on birch (Betula pubescens Ehrh.) growth in Fnjoskadalur Valley, northern Iceland. Dendrochronologia, 25, 135-143.

Schweingruber, F.H. (2007) Wood structure and environment. Springer, Berlin Heidelberg.

Sonesson, M. \& Hoogesteger, J. (1983) Recent tree-line dynamics (Betula pubescens Ehrh. ssp. tortuosa (Ledeb.) Nyman) in northern Sweden. Nordicana, 47, 47-54. 
Appendix S3 Historical anthropozoogenic impact in the Torneträsk area. The points of relatively intense historical impact identified by Emanuelsson (1987) were relocated in the field and the distances between these points and the studied tree line sites were recorded by a GPS (see Table 2).

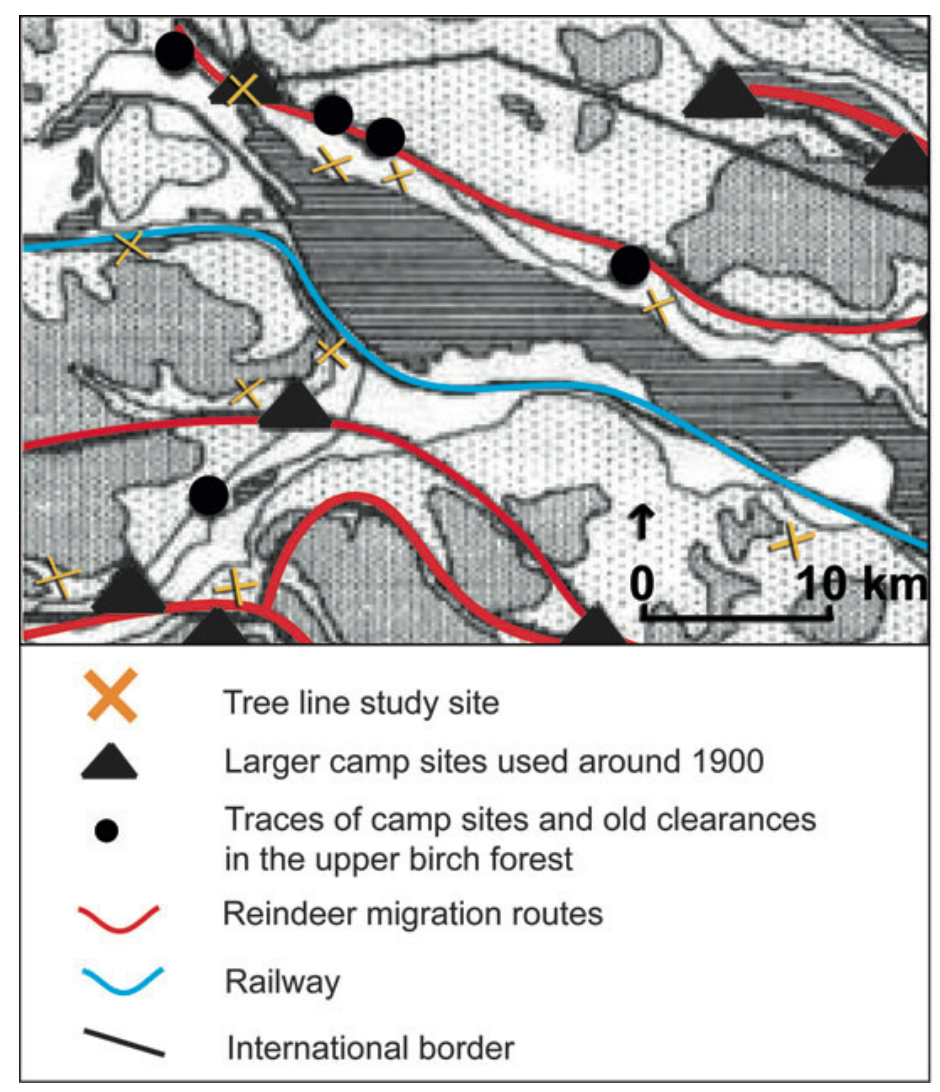

\section{$\underline{\text { Reference }}$}

Emanuelsson, U. (1987) Human influence on vegetation in the Torneträsk area during the last three centuries. Ecological Bulletins, 38, 95-111. 


\section{References}

ACIA, 2005: Arctic Climate Impact Assessment. Cambridge: Cambridge University Press.

Alexandersson, H., Karlström, C., and Larsson-McCann, S., 1991: Temperature and precipitation in Sweden, 1961-90. Reference normals. SMHI Reports, Meteorology and Climatology, 81: 1-87.

Bryn, A. and Daugstad, K., 2001: Summer farming in the subalpine birch forest. In Wielgolaski, F. E. (ed.), Nordic mountain birch ecosystems. New York: UNESCO, Paris and Parthenon, 307-315.

Cairns, D. M. and Moen, J., 2004: Herbivory influences treelines. Journal of Ecology, 92: 1019-1024.

Callaghan, T.V., Werkman, B.R., and Crawford, R.M.M., 2002: The tundra-taiga interface and its dynamics: concepts and applications. Ambio, 12: 6-14.

Callaghan, T.V., Bergholm, F., Christensen, T.R., Jonasson, C., Kokfelt, U., and Johansson, M., 2010: A new climate era in the sub-Arctic: accelerating climate changes and multiple impacts. Geophysical Research Letters, 37, L14705.

Cherosov, M.M., Isaev, A.P., Mironova, S.I., Lytkina, L.P., Gavrilyeva, L.D., Sofronov, R.R., Arzhakova, A.P., Barashkova, N.V., Ivanov, I.A., Shurduk, I.F., Efimova, A.P., Karpov, N.S., Timofeyev, P.A., and Kuznetsova, L.V., 2010: Vegetation and human activity. In Troeva, E.I., Isaev, A.P., Cherosov, M.M., and Karpov, N.S. (eds.) The far North: plant biodiversity and ecology of Yakutia. Berlin: Springer, 261-295.

Dalen, L. and Hofgaard, A., 2005: Differential regional treeline dynamics in the Scandes Mountains. Arctic, Antarctic, and Alpine Research, 37: 284-296. 
Danby, R.K. and Hik, D.S., 2007: Variability, contingency and rapid change in recent subarctic alpine treeline dynamics. Journal of Ecology, 95: 352-363.

Eckstein, D., Hoogesteger, J. and Holmes, R.L., 1991: Insectrelated differences in growth of birch and pine at northern treeline in Swedish Lapland. Holarctic Ecology, 14: 18-23.

Ellenberg, H., 1988: Vegetation ecology of central Europe, $4^{\text {th }}$ edn. Cambridge: Cambridge University Press.

Emanuelsson, U., 1987: Human influence on vegetation in the Torneträsk area during the last three centuries. Ecological Bulletins, 38: 95-111.

Fritts, H.C., 1976: Tree rings and climate. NewYork: Academic Press.

Hållmarker, M., 2002: Forestline changes in Abisko. MSc Thesis, Gothenburg: University of Gothenburg, Sweden.

Harding, R., Kuhry, P., Christensen, T.R., Sykes, M.T., Dankers, R. and van der Linden, S., 2002: Climate feedbacks at the tundra-taiga interface. Ambio, 12: $47-55$.

Harsch, M.A., Hulme, P.E., McGlone, M.S. and Duncan, R.P., 2009: Are treelines advancing? A global meta-analysis of treeline response to climate warming. Ecology Letters, 12: 1040-1049.

Helle, T., 2001: Mountain birch forests and reindeer husbandry. In Wielgolaski, F.E. (ed.) Nordic mountain birch ecosystems. New York: UNESCO, Paris and Parthenon, 279-291.

Hofgaard, A., 1997: Inter-relationships between treeline position, species diversity, land use and climate change in the central Scandes Mountains of Norway. Global Ecology and Biogeography Letters, 6: 419-429.

Hofgaard, A., 1999: The role of 'natural' landscapes influenced by man in predicting 
responses to climate change. Ecological Bulletins, 47: 160-167.

Holmgren, B. and Tjus, M., 1996: Summer air temperatures and treeline dynamics at Abisko. Ecological Bulletins, 45: 159-169.

Holtmeier, F.K. and Broll, G., 2005: Sensitivity and response of Northern Hemisphere elevational and polar treelines to environmental change at landscape and local scales. Global Ecology and Biogeography, 14: 395-410.

Holtmeier, F.K. and Broll, G., 2007: Treeline advance—driving processes and adverse factors. Landscape Online, 1: 1-33.

Holtmeier, F.K. and Broll, G., 2010: Wind as an ecological agent at treelines in North America, the Alps, and the European Subarctic. Physical Geography, 31: 203233.

Holtmeier, F.K., Broll, G., Müterthies, A. and Anschlag, K., 2003: Regeneration in the treeline ecotone: northern Finnish Lapland. Fennia, 181: 103-128.

Hoogesteger, J. and Karlsson, P.S., 1992: Effects of defoliation on radial stem growth and photosynthesis in the mountain birch (Betula pubescens ssp. tortuosa). Functional Ecology, 6: 317-323.

Ims, R.A., Yoccoz, N.G., Bråthen, K.A., Fauchald, P., Tveraa, T. and Hausner, V., 2007: Can reindeer overabundance cause a trophic cascade? Ecosystems, 10: $607-622$.

Kallio, P. and Lehtonen, J., 1973: Birch forest damage caused by Oporinia autumnata (Bkh.) in 1956-66 in Utsjoki, North Finland. Reports from the Kevo Subarctic Research Station, 10: 55-59.

Kaplan, J.O. and New, M., 2006: Arctic climate change with a $2{ }^{\circ} \mathrm{C}$ global warming: timing, climate patterns and vegetation change. Climatic Change, 79: 213241. 
Kharuk, V.I., Ranson, K.J., Im, S.T. and Naurzbaev, M.M., 2006: Forest-tundra larch forests and climatic trends. Russian Journal of Ecology, 37: 291-298.

Kirchhefer, A.J., 1996: A dendrochronological study on the effect of climate, site, and insect outbreaks on the growth of Betula pubescens collections in northern Norway. Palaeoclimate Research, 20: 93-106.

Kullman, L., 2005: Wind-conditioned $20^{\text {th }}$ century decline of birch treeline vegetation in the Swedish Scandes. Arctic, 58: 286-294.

Kullman, L. and Öberg, L., 2009: Post-Little Ice Age treeline rise and climate warming in the Swedish Scandes: a landscape ecological perspective. Journal of Ecology, 97: 415-429.

Lehtonen, J. and Heikkinen, R.K., 1995: On the recovery of mountain birch after Epirrita damage in Finnish Lapland, with a particular emphasis on reindeer grazing. Écoscience, 2: 349-356.

Lundgren, M., 1999: Nutida trädgränsförändringar i Abisko området, norra Lappland. [Recent treeline changes in the Abisko area, northern Lapland]. MSc Thesis, Umeå University, Umeå (in Swedish).

Lundh, N.G., 2001: Trädgränsen—mer kultiverad än sitt rykte? [The treeline-more cultivated than its reputation?] Fauna och Flora, 2: 79-89 (in Swedish with English summary).

Masek, J.G., 2001: Stability of boreal forest stands during recent climate change: evidence from LANDSAT satellite imagery. Journal of Biogeography, 28: 967-976.

Moen, J., Aune, K., Edenius, L. and Angerbjörn, A., 2004: Potential effects of climate change on tree-line position in the Swedish mountains. Ecology and Society, 9: 16 . 
Moen, J., Cairns, D.M. and Lafon, C.W., 2008: Factors structuring the treeline ecotone in Fennoscandia. Plant Ecology and Diversity, 1: 77-87.

Payette, S., 2007: Contrasted dynamics of northern Labrador treelines caused by climate change and migrational lag. Ecology, 88: 770-780.

Payette, S., Eronen, M. and Jasinski, J.P.P., 2002: The circumboreal tundra-taiga interface: late Pleistocene and Holocene changes. Ambio, 12: 15-22.

Persson, E., 1952: Träd-och skoggränsstudier på nordsidan av Torneträsk [Tree- and forestline studies on the northern side of Lake Torneträsk]. MSc Thesis, Lund University, Lund (in Swedish).

Rees, W.G., Brown, I., Mikkola, K., Virtanen, T. and Werkman, B.R., 2002: How can the dynamics of the tundra-taiga boundary be remotely monitored? Ambio, 12: $56-62$.

Saelthun, N.R. and Barkved, L.J., 2003: Climate change scenarios for the Scannet Region. Norwegian Institute for Water Research (NIVA) Report SNO 4663. NIVA, Oslo.

Sandberg, G., 1940: Den pågående klimatförändringen [The ongoing climate changes]. Svenska Vall- och Mosskulturföreningens Kvartalsskrift, 2: 163-178 (in Swedish).

Sandberg, G., 1963: Växtvärlden i Abisko nationalpark [Botany of the Abisko National Park]. In Curry-Lindahl, K. (ed.) Natur i Lappland. Uppsala: Bokförlaget Svensk Natur, 885-908 (in Swedish).

Seppälä, M. and Rastas, J., 1980: Vegetation map of northernmost Finland with special reference to subarctic forest limits and natural hazards. Fennia, 158: $41-61$.

Shiyatov, S., Terent'ev, M., Fomin, V. and Zimmermann, N., 2007: Elevational and 
horizontal shifts of the upper boundaries of open and closed forests in the Polar Urals in the $20^{\text {th }}$ century. Russian Journal of Ecology, 38: 223-227.

Sonesson, M. and Hoogesteger, J., 1983: Recent tree-line dynamics (Betula pubescens Ehrh. ssp. tortuosa (Ledeb.) Nyman) in northern Sweden. Nordicana, 47: 4754.

Sonesson, M., Osborne, C. and Sandberg, G., 1994: Epiphytic lichens as indicators of snow depth. Arctic, Antarctic, and Alpine Research, 26: 159-165.

Speed, J.D.M., Austrheim, G., Hester, A.J., and Mysterud, A., 2010: Experimental evidence for herbivore limitation of the treeline. Ecology, 91: 3414-3420.

Sveinbjörnsson, B., Hofgaard, A., and Lloyd, A.H., 2002: Natural causes of the tundra-taiga boundary. Ambio, 12: 23-29.

Tenow, O., 1972: The outbreaks of Oporinia autumnata Bkh. and Operophthera spp. (Lep.: Geometridae) in the Scandinavian mountain chain and northern Finland 1862-1968.Zoologiska Bidrag från Uppsala, 2: 1-107.

Tenow, O., Bylund, H., Nilssen, A.C. and Karlsson, P.S., 2005: Long-term influence of herbivores on northern birch forests. In Wielgolaski, F.E. (ed.) Plant ecology, herbivory, and human impact in Nordic mountain birch forests. Berlin: Springer-Verlag, 166-181.

Truong, C., Palme, A.E. and Felber, F., 2006: Recent invasion of the mountain birch Betula pubescens ssp. tortuosa above the treeline due to climate change: genetic and ecological study in northern Sweden. Journal of Evolutionary Biology, 20: 369-380.

Van Bogaert, R., Walker, D., Jia, G.J., Grau, O., Hallinger, M., De Dapper, M., Jonasson, C. and Callaghan, T.V., 2007: Recent changes in vegetation. In Richter-Menge, J. (ed.) Arctic Report Card 2007. Washington: National 
Oceanic and Atmospheric Administration (NOAA), 33-40.

Van Bogaert, R., Jonasson, C., De Dapper, M. and Callaghan, T.V., 2009:

Competitive interaction between aspen and birch moderated by invertebrate and vertebrate herbivores and climate warming. Plant Ecology and Diversity, 2: $221-232$.

Van Bogaert, R., Jonasson, C., De Dapper, M. and Callaghan, T.V., 2010: Range expansion of thermophilic aspen (Populus tremula L.) in sub-Arctic Sweden. Arctic, Antarctic, and Alpine Research, 42: 362-375.

Veijola, P., 1998: The northern timberline and timberline forests in Fennoscandia. The Finnish Forest Research Institute Research Papers, 672: 1-242.

Vlassova, T.K., 2002: Human impacts on the tundra-taiga zone dynamics: the case of the Russian lesotundra. Ambio, 12: 30-36.

Von Middendorf, A., 1864: Sibirische Reisen. Band IV, Teil 1: Ubersicht über die Natur Nord- und Ostsibiriens. Vierte Lieferung: die Gewachse Sibiriens. [Siberian journey. Volume 4, Part 1. Overview of the nature in Northern and Eastern Siberia. The Siberian vegetation]. St Petersburg: Buchdruckerei der Kaiserlichen Akademie der Wissenschaften (in German).

Wolf, A., Callaghan, T.V. and Larson, K., 2008a: Future changes in vegetation and ecosystem function of the Barents region. Climatic Change, 87: 51-73.

Wolf, A., Kozlov, M.V. and Callaghan, T.V., 2008b: Impact of non-outbreak insect damage on vegetation in northern Europe will be greater than expected during a changing climate. Climatic Change, 87: 91-106. 


\section{Tables}

Table 1. Previous field studies on observed treeline shifts and their presumed causes

in the Torneträsk area of sub-Arctic Sweden.

\begin{tabular}{|c|c|c|c|c|c|}
\hline Author & Year & Area & Methods & Results & $\begin{array}{l}\text { Presumed } \\
\text { attribution }\end{array}$ \\
\hline Sandberg & 1940 & Mount Nuolja & Repeat Observation & $\begin{array}{l}\text { Establishment of } 0.5 \mathrm{~m} \text { tall } \\
\text { birch saplings during warm } \\
\text { 1930s up to } 200 \mathrm{~m} \text { above the } \\
\text { upper limit of the closed forest }\end{array}$ & Climate warming \\
\hline Persson & 1952 & North-Torneträsk & $\begin{array}{l}\text { Observations; } \\
\text { elevational } \\
\text { measurements of tree } \\
\text { line ecotone }\end{array}$ & $\begin{array}{l}\text { Contrasting tree line types and } \\
\text { age structure }\end{array}$ & $\begin{array}{l}\text { Contrasting site } \\
\text { history, climate, } \\
\text { geomorphological } \\
\text { and biotic processes }\end{array}$ \\
\hline Sandberg & 1963 & Mount Nuolja & $\begin{array}{l}\text { Repeat observations; } \\
\text { repeat photography }\end{array}$ & $\begin{array}{l}\text { Forest densification at lower } \\
\text { boundary of tree line ecotone. } \\
\text { No increased abundance of } \\
\text { birch at upper boundary. }\end{array}$ & Climate warming \\
\hline $\begin{array}{l}\text { Sonesson \& } \\
\text { Hoogesteger }\end{array}$ & 1983 & West- Torneträsk & $\begin{array}{l}\text { Elevational transects; } \\
\text { dendrochronology }\end{array}$ & $\begin{array}{l}\text { Elevational advance of tree } \\
\text { line ecotone by } 20-50 \mathrm{~m} \\
\text { between } 1937-1977\end{array}$ & Climate warming \\
\hline Emanuelsson & 1987 & Whole Torneträsk & $\begin{array}{l}\text { Ethnographical } \\
\text { historical research; } \\
\text { aerial and ground } \\
\text { observations; } \\
\text { interviewing } \\
\text { local people; } \\
\text { repeat photography }\end{array}$ & $\begin{array}{l}\text { Elevational advance } \\
\text { and densification of tree line } \\
\text { ecotone since } 1900 . \\
\text { Significant anthropozoogenic } \\
\text { impact on the tree line in } \\
\text { period } 1600-1920\end{array}$ & $\begin{array}{l}\text { Recent decrease in } \\
\text { anthropo-zoogenic } \\
\text { impact }\end{array}$ \\
\hline $\begin{array}{l}\text { Holmgren } \\
\& \text { Tjus }\end{array}$ & 1996 & Mount Nuolja & $\begin{array}{l}\text { Field observations; } \\
\text { literature review; } \\
\text { climate analysis }\end{array}$ & $\begin{array}{l}\text { Elevational advance } \\
\text { of the tree line ecotone by } \\
\text { c. } 40 \mathrm{~m} \text { between } 1930-1996\end{array}$ & Climate warming \\
\hline Lundgren & 1999 & Mount Nuolja & $\begin{array}{l}\text { Repeat tree line } \\
\text { measurements 1971- } \\
1998\end{array}$ & $\begin{array}{l}\text { Elevational advance of upper } \\
\text { limit of tree-sized birches (>2 } \\
\text { m) by } 22-46 \mathrm{~m}\end{array}$ & Climate warming \\
\hline Hållmarker & 2002 & Mount Nuolja & $\begin{array}{l}\text { Remote sensing; } \\
\text { repeat photography }\end{array}$ & $\begin{array}{l}\text { Elevational advance of lower } \\
\text { boundary of tree line ecotone } \\
\text { by c. } 20 \mathrm{~m} \text { between } 1959- \\
2000\end{array}$ & $\begin{array}{l}\text { Climate warming, } \\
\text { reduced anthropo-zoo- } \\
\text { genic impact, moth } \\
\text { outbreaks, } \\
\text { geomorphology }\end{array}$ \\
\hline $\begin{array}{l}\text { Cairns \& } \\
\text { Moen }\end{array}$ & 2004 & $\begin{array}{l}\text { Southwest- } \\
\text { Torneträsk }\end{array}$ & $\begin{array}{l}\text { Field measurements; } \\
\text { herbivory analysis }\end{array}$ & $\begin{array}{l}\text { Differential reindeer grazing } \\
\text { impacts cause differential tree } \\
\text { line shifts and structure }\end{array}$ & $\begin{array}{l}\text { Differential reindeer } \\
\text { grazing pressure }\end{array}$ \\
\hline $\begin{array}{l}\text { Dalen \& } \\
\text { Hofgaard }\end{array}$ & 2005 & $\begin{array}{l}\text { Southwest- } \\
\text { Torneträsk }\end{array}$ & $\begin{array}{l}\text { Dendrochronology; } \\
\text { field measurements }\end{array}$ & $\begin{array}{l}\text { Major recruitment phase at } \\
\text { upper boundary of tree line } \\
\text { ecotone in } 1960 \text { s; possibly } \\
\text { advancing tree line }\end{array}$ & $\begin{array}{l}\text { Moth outbreak of } \\
\text { 1955, herbivory, } \\
\text { climate warming }\end{array}$ \\
\hline Truong et al & 2006 & $\begin{array}{l}\text { Southwest- } \\
\text { Torneträsk }\end{array}$ & $\begin{array}{l}\text { Field observations; } \\
\text { genetic study }\end{array}$ & $\begin{array}{l}\text { Birch seedlings found up to } \\
500 \mathrm{~m} \text { above the upper limit } \\
\text { of the closed forest }\end{array}$ & Climate warming \\
\hline
\end{tabular}


Table 2. Documented treeline shifts and site conditions for 10 sites studied in the Torneträsk area of sub-Arctic Sweden for the period 1912-2009 (see Fig. 1). Independently obtained results from repeat photography, repeat transect measurements and dendrochronological analysis were cross-referenced to determine the shift of the lower boundary of the treeline ecotone. Browsing damage was classified visually and for five sites also by dendrochronological analysis (the values listed in brackets). So as not to bias the results, Mount Nuolja (site S3), for which the two treeline sites were not randomly selected, was not included in the calculation of the mean elevational shift of the treeline in the Torneträsk area. Pearson correlation coefficients and $R^{2}$-values (the proportion of explained variance in documented treeline shifts) obtained by forward selection of the different variables are listed at the bottom of the table.

\begin{tabular}{|c|c|c|c|c|c|c|c|c|}
\hline & Site & $\begin{array}{l}\text { Elevational } \\
\text { shift of tree } \\
\text { line eco- } \\
\text { tone }(\mathrm{m})\end{array}$ & $\begin{array}{c}\text { Aspect } \\
\left({ }^{\circ}\right)\end{array}$ & $\begin{array}{l}\text { Inclina- } \\
\text { tion }\left(^{\circ}\right)\end{array}$ & $\begin{array}{l}\text { Anthropozoo- } \\
\text { genic impact } \\
\text { (distance in m } \\
\text { from previous } \\
\text { camp or } \\
\text { railway) }\end{array}$ & $\begin{array}{l}\text { Snow depth } \\
\text { (m) }\end{array}$ & $\begin{array}{l}\text { Browsed } \\
\text { tree line } \\
\text { birches }(\%)\end{array}$ & $\begin{array}{l}\text { Polycormic } \\
\text { tree line } \\
\text { birches }(\%)\end{array}$ \\
\hline & $\mathrm{N} 1$ & $-120 \pm 20$ & 220 & 29 & 1210 & 0.5 & $47(81)$ & 42 \\
\hline & $\mathrm{N} 2$ & $0 \pm 10$ & 205 & 17 & 720 & 0.7 & $35(73)$ & 24 \\
\hline & N3 & $+50 \pm 5$ & 220 & 26 & 180 & 1.2 & 42 & 66 \\
\hline & $\mathrm{N} 4$ & $0 \pm 10$ & 180 & 41 & 910 & 0.3 & 29 & 63 \\
\hline & S1 & $+40 \pm 15$ & 155 & 0 & 490 & 1.0 & $51(64)$ & 52 \\
\hline & S2 & $+50 \pm 5$ & 15 & 27 & 190 & 0.9 & 39 & 58 \\
\hline & S3-East & $+60 \pm 5$ & 80 & 26 & 220 & 1.2 & $43(53)$ & 60 \\
\hline & S3-South & $0 \pm 10$ & 170 & 10 & 800 & 0.3 & $29(72)$ & 43 \\
\hline & S4 & $+145 \pm 10$ & 200 & 26 & 210 & 1.2 & 32 & 68 \\
\hline & S5 & $0 \quad \pm 5$ & 50 & 40 & 960 & 0.5 & 16 & 74 \\
\hline & $\begin{array}{l}\text { All except } \\
\text { S3 }\end{array}$ & $+24 \pm 2$ & & & & & & \\
\hline$r(P)$ & All & & $-0.24(0.45)$ & $-0.06(0.87)$ & $-0.46(0.03)$ & $0.44(0.04)$ & $0.24(0.48)$ & $0.44(0.17)$ \\
\hline$R^{2}$ & All & & 0 & 0 & 0.35 & 0.59 & 0.59 & 0.59 \\
\hline
\end{tabular}


Table 3. Treeline shifts in the Swedish Torneträsk area identified by repeat photography analysis (upper part) and compared with dendrochronological analysis (bottom part) for the elevational transects. The geographical scale of the study ranged from an individual mountain (Mount Nuolja, site $\mathrm{M}_{\mathrm{S} 3}$ ) to the landscape scale (sites N1, N2 and S1). Trees were grouped into three establishment periods: individuals established (1) before 1900; during the peak of intensive reindeer management practices, (2) in the period 1900-63; before the reindeer population reached its longterm minimum, and (3) in the period 1964-2006; the most recent period during which reindeer population numbers were initially very low and subsequently increased again.

\begin{tabular}{|c|c|c|c|c|c|c|c|c|}
\hline \multicolumn{9}{|c|}{ Scale } \\
\hline & & \multicolumn{2}{|c|}{ Individual mountain $\left(\mathrm{M}_{\mathrm{S} 3}\right)$} & \multicolumn{2}{|c|}{ Torneträsk } & \multicolumn{2}{|c|}{$1 \mathrm{andscape}$} & area \\
\hline & & East Slope & South Slope & N1 & & $\mathrm{N} 2$ & & $\mathrm{~S} 1$ \\
\hline \multirow[t]{5}{*}{$\begin{array}{l}\text { Dynamics } \\
\text { of tree line } \\
\text { ecotone }\end{array}$} & $\begin{array}{l}\text { Elevational shift } \\
(\mathrm{m}) \text { of the tree line } \\
\text { ecotone for the } \\
\text { period } 1912-2009\end{array}$ & $+60 \pm 5$ & $0 \pm 5$ & $-120 \pm 5$ & & $0 \pm 5$ & & $40 \pm 5$ \\
\hline & Upper transect: & $\begin{array}{l}\text { Number of } \\
\text { individuals }(\%)\end{array}$ & $\begin{array}{l}\text { Number of } \\
\text { individuals }(\%)\end{array}$ & $\begin{array}{l}\text { Number of } \\
\text { individuals }(\%)\end{array}$ & $\begin{array}{l}\text { Numbe } \\
\text { individ }\end{array}$ & 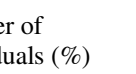 & $\begin{array}{l}\text { Numbe } \\
\text { individ }\end{array}$ & $\begin{array}{l}\text { er of } \\
\text { luals }(\%)\end{array}$ \\
\hline & $>1900$ & $0 \pm 0 \quad(0 \pm 0 \%)$ & $3 \pm 1 \quad(8 \pm 3 \%)$ & $0 \pm 0 \quad(0 \pm 0 \%)$ & $16 \pm 1$ & $(66 \pm 4 \%)$ & $0 \pm 0$ & $(0 \pm 0 \%)$ \\
\hline & $1900-1963$ & $0 \pm 1 \quad(0 \pm 4 \%)$ & $0 \pm 1 \quad(0 \pm 3 \%)$ & $5 \pm 1 \quad(25 \pm 5 \%)$ & $4 \pm 1$ & $(17 \pm 4 \%)$ & $11 \pm 1$ & $(42 \pm 4 \%)$ \\
\hline & 1964-2006 & $23 \pm 1(100 \pm 4 \%)$ & $33 \pm 1 \quad(92 \pm 3 \%)$ & $15 \pm 1(75 \pm 5 \%)$ & $4 \pm 1$ & $(17 \pm 4 \%)$ & $15 \pm 1$ & $(58 \pm 4 \%)$ \\
\hline \multirow{7}{*}{$\begin{array}{c}\text { Age } \\
\text { structure } \\
\text { of tree line } \\
\text { ecotone }\end{array}$} & $\begin{array}{l}\text { Middle transect: } \\
>1900\end{array}$ & $0 \pm 0 \quad(0 \pm 0 \%)$ & $2 \pm 1 \quad(10 \pm 5 \%)$ & - & & - & & - \\
\hline & $1900-1963$ & $1 \pm 1 \quad(5 \pm 5 \%)$ & $1 \pm 1 \quad(5 \pm 5 \%)$ & - & & - & & - \\
\hline & $1964-2006$ & $19 \pm 1(95 \pm 5 \%)$ & $17 \pm 1(85 \pm 5 \%)$ & - & & - & & - \\
\hline & Lower transect: & & & & & & & \\
\hline & $>1900$ & $2 \pm 1 \quad(6 \pm 3 \%)$ & $36 \pm 3 \quad(28 \pm 3 \%)$ & - & & - & & - \\
\hline & $1900-1963$ & $1 \pm 1 \quad(3 \pm 3 \%)$ & $0 \pm 3 \quad(0 \pm 3 \%)$ & - & & - & & - \\
\hline & 1964-2006 & $30 \pm 1(90 \pm 3 \%)$ & $94 \pm 3 \quad(72 \pm 3 \%)$ & - & & - & & - \\
\hline
\end{tabular}


Table 4. Significant $(\mathrm{P}<0.05)$ disturbance events at the tree line in the Swedish Torneträsk area for the period 1800-2006. The geographical scale of the study ranged from an individual mountain (Mount Nuolja, site $\mathrm{M}_{\mathrm{S} 3}$ ) to the landscape scale (sites N1, N2 and S1). Ring-width chronologies of birch and pine individuals sampled below the tree line ecotone were used as a reference. Major disturbance events are given in bold and were defined as events that affected $50 \%$ or more of the tree line individuals in two or more different sites. The number of replicates is given in brackets. Note that the list of disturbance events is not exhaustive, particularly for the period 1800-1900 for which fewer replicates were available.

\begin{tabular}{|c|c|c|c|c|c|c|c|c|}
\hline \multirow[t]{2}{*}{$\begin{array}{l}\text { Growth } \\
\text { Reduc- } \\
\text { tion } \\
\text { Period }\end{array}$} & \multicolumn{2}{|c|}{$\begin{array}{l}\text { Individual } \\
\text { mountain } \\
\left(\mathrm{M}_{\mathrm{S} 3}\right)\end{array}$} & \multicolumn{3}{|c|}{ Torneträsk landscape } & \multirow[t]{2}{*}{$\begin{array}{l}\text { Presumed } \\
\text { Event }\end{array}$} & \multirow[t]{2}{*}{$\begin{array}{l}\text { Tree-ring } \\
\text { anatomical } \\
\text { wood features }\end{array}$} & \multirow[t]{2}{*}{ Validation } \\
\hline & $\begin{array}{l}\text { East } \\
\text { Slope }\end{array}$ & $\begin{array}{l}\text { South } \\
\text { Slope }\end{array}$ & N1 & $\mathrm{N} 2$ & $\mathrm{~S} 1$ & & & \\
\hline $1801-11$ & - & - & - & $100 \%(3)$ & - & $\begin{array}{l}\text { Reindeer browsing } \\
1808\end{array}$ & $\begin{array}{l}\text { Browsing scar } \\
1808\end{array}$ & $\begin{array}{l}\text { Peaking reindeer } \\
\text { population }\end{array}$ \\
\hline $1853-59$ & - & - & - & $67 \%(6)$ & - & $\begin{array}{l}\text { Reindeer browsing } \\
1853,1857\end{array}$ & $\begin{array}{l}\text { Browsing scars } \\
1853,1857\end{array}$ & $\begin{array}{l}\text { Peaking reindeer } \\
\text { population }\end{array}$ \\
\hline 1863-64 & $0 \%(2)$ & $50 \%(2)$ & - & $50 \%(6)$ & - & $\begin{array}{l}\text { Reindeer browsing } \\
1863\end{array}$ & $\begin{array}{l}\text { Browsing scars } \\
1863\end{array}$ & $\begin{array}{l}\text { Peaking reindeer } \\
\text { population }\end{array}$ \\
\hline $1900-01$ & $50 \%(2)$ & $50 \%(2)$ & - & $33 \%(6)$ & - & $\begin{array}{l}\text { After-effect cold } \\
\text { summer } 1900\end{array}$ & $\begin{array}{l}\text { Small ring in old } \\
\text { and young } \\
\text { individuals } 1901\end{array}$ & $\begin{array}{l}\text { 1900:exceptionally } \\
\text { cold: } 4^{\circ} \mathrm{C} \text { below } \\
\text { long-term mean }\end{array}$ \\
\hline 1902-04 & $25 \%(8)$ & $100 \%(4)$ & - & $71 \%(14)$ & - & $\begin{array}{l}\text {-Moth defoliation } \\
\text { old birches 1902- } \\
\text { 1903 (N2) } \\
\text {-Reindeer browsing } \\
\text { young birches } 1903 \\
\left(M_{S 3}\right)\end{array}$ & $\begin{array}{l}\text {-White ring 1902- } \\
1903(\mathrm{~N} 2) \\
\text {-Browsing scars } \\
1903\left(\mathrm{M}_{\mathrm{S} 3}\right)\end{array}$ & $\begin{array}{l}\text {-Reported moth } \\
\text { outbreak in } \\
\text { N-Fennoscandia } \\
\text { (Tenow, 1972) } \\
\text {-Average reindeer } \\
\text { population }\end{array}$ \\
\hline $1909-11$ & $33 \%(12)$ & $25 \%(4)$ & - & $71 \%(14)$ & - & $\begin{array}{l}\text { Reindeer browsing } \\
1909,1911\end{array}$ & $\begin{array}{l}\text { Browsing scars } \\
1909,1911\end{array}$ & $\begin{array}{l}\text { Peaking reindeer } \\
\text { population }\end{array}$ \\
\hline 1919 & $50 \%(12)$ & $0 \%(10)$ & - & $13 \%(16)$ & - & $\begin{array}{l}\text { Reindeer browsing } \\
1919\end{array}$ & $\begin{array}{l}\text { Browsing scars } \\
1919\end{array}$ & $\begin{array}{l}\text { Average reindeer } \\
\text { population }\end{array}$ \\
\hline 1925 & $17 \%(12)$ & $10 \%(10)$ & - & $13 \%(16)$ & $0 \%(2)$ & $\begin{array}{l}\text { Reindeer browsing } \\
1925\end{array}$ & $\begin{array}{l}\text { Browsing scars } \\
1925\end{array}$ & $\begin{array}{l}\text { High reindeer } \\
\text { population }\end{array}$ \\
\hline 1929 & $50 \%(12)$ & $60 \%(10)$ & $100 \%(2)$ & $50 \%(24)$ & $67 \%(3)$ & $\begin{array}{l}\text { Reindeer browsing } \\
1929\end{array}$ & $\begin{array}{l}\text { Browsing scars } \\
1929\end{array}$ & $\begin{array}{l}\text { Peaking reindeer } \\
\text { population }\end{array}$ \\
\hline $1934-35$ & $14 \%(14)$ & $10 \%(10)$ & $100 \%(2)$ & $0 \%(24)$ & $25 \%(4)$ & $\begin{array}{l}\text { Reindeer browsing } \\
1934\end{array}$ & $\begin{array}{l}\text { Browsing scars } \\
1934\end{array}$ & $\begin{array}{l}\text { High reindeer } \\
\text { population }\end{array}$ \\
\hline 1955-58 & $33 \%(10)$ & $50 \%(10)$ & $0 \%(5)$ & $13 \%(30)$ & $60 \%(5)$ & $\begin{array}{l}\text { Moth defoliation } \\
1955\end{array}$ & White ring 1955 & $\begin{array}{l}\text { E. autumnata } \\
\text { outbreak } 1955\end{array}$ \\
\hline 1964-68 & $50 \%(12)$ & $83 \%(12)$ & $20 \%(5)$ & $63 \%(30)$ & $0 \%(5)$ & $\begin{array}{l}\text { Moth defoliation } \\
1964\left(\mathrm{M}_{\mathrm{S} 3}\right) \\
\text { Moth defoliation } \\
1965 \text { (N1-N2) }\end{array}$ & $\begin{array}{l}\text { White ring } 1964 \\
\left(\mathrm{M}_{\mathrm{S} 3}\right) \\
\text { White ring } 1965 \\
(\mathrm{~N} 1-\mathrm{N} 2)\end{array}$ & $\begin{array}{l}\text { E. autumnata peak } \\
1964\left(\mathrm{M}_{\mathrm{S} 3}\right) \\
\text { O. brumata } \text { outbreak } \\
1965(\mathrm{~N} 1-\mathrm{N} 2)\end{array}$ \\
\hline $1975-76$ & $33 \%(18)$ & $18 \%(18)$ & $10 \%(20)$ & $15 \%(32)$ & $10 \%(10)$ & $\begin{array}{l}\text { After-effect cold } \\
\text { summer } 1975\end{array}$ & $\begin{array}{l}\text { Small ring in old } \\
\text { and young } \\
\text { individuals } 1976\end{array}$ & $\begin{array}{l}\text { 1975:exceptionally } \\
\text { cold: } 3{ }^{\circ} \mathrm{C} \text { below } \\
\text { long-term mean }\end{array}$ \\
\hline 1979 & $35 \%(34)$ & $45 \%(22)$ & $6 \%(32)$ & $30 \%(32)$ & $50 \%(12)$ & $\begin{array}{l}\text { Reindeer browsing } \\
1979\end{array}$ & $\begin{array}{l}\text { Browsing scars } \\
1979\end{array}$ & $\begin{array}{l}\text { High reindeer } \\
\text { population }\end{array}$ \\
\hline 1984 & $17 \%(46)$ & $21 \%(33)$ & $26 \%(38)$ & $30 \%(34)$ & $25 \%(16)$ & Frost damage & Frost ring 1984 & $\begin{array}{l}\text { May: } 27 \text { days }+12^{\circ} \mathrm{C} \\
\text { June: } 3 \text { days }-1.3^{\circ} \mathrm{C}\end{array}$ \\
\hline 1985 & $9 \%(46)$ & $21 \%(33)$ & $21 \%$ & $30 \%(36)$ & $29 \%$ & $\begin{array}{l}\text { Reindeer browsing } \\
1985\end{array}$ & $\begin{array}{l}\text { Browsing scars } \\
1985\end{array}$ & $\begin{array}{l}\text { Peaking reindeer } \\
\text { population }\end{array}$ \\
\hline $1991-92$ & $23 \%(46)$ & $28 \%(49)$ & $11 \%(38)$ & $18 \%(36)$ & $11 \%(18)$ & $\begin{array}{l}\text { Reindeer browsing } \\
1991-1992\end{array}$ & $\begin{array}{l}\text { Browsing scars } \\
1991-1992\end{array}$ & $\begin{array}{l}\text { High reindeer } \\
\text { population }\end{array}$ \\
\hline $1994-96$ & $37 \%(62)$ & $59 \%(56)$ & $21 \%$ & $23 \%$ & $11 \%(18)$ & $\begin{array}{l}\text {-Moth defoliation } \\
1994 \text { (old birches) } \\
\text {-Reindeer browsing } \\
1994 \text { (young birches) }\end{array}$ & $\begin{array}{l}\text {-White ring } 1994 \\
\text {-Browsing scars } \\
1994\end{array}$ & $\begin{array}{l}\text {-E. autumnata peak } \\
1994 \\
\text {-Average reindeer } \\
\text { population }\end{array}$ \\
\hline $1997-98$ & $8 \%(62)$ & $11 \%(56)$ & $5 \%(38)$ & $15 \%(37)$ & $31 \%(26)$ & $\begin{array}{l}\text { Reindeer browsing } \\
1997-1998\end{array}$ & $\begin{array}{l}\text { Browsing scars } \\
1997-1998\end{array}$ & $\begin{array}{l}\text { Average reindeer } \\
\text { population }\end{array}$ \\
\hline $2005-06$ & $4 \%(101)$ & $7 \%(97)$ & $8 \%(43)$ & $20 \%$ & $15 \%(30)$ & $\begin{array}{l}\text { Reindeer browsing } \\
2005-2006\end{array}$ & $\begin{array}{l}\text { Browsing scars } \\
2005-2006\end{array}$ & $\begin{array}{l}\text { High reindeer } \\
\text { population }\end{array}$ \\
\hline
\end{tabular}




\section{Figure legends}

Fig. 1. The Torneträsk study area in sub-Arctic Sweden. The locations of the historical transects and photo points that have been revisited to study changes in the tree line ecotone are indicated.

Fig. 2. Tree line site S4 on the south side of Lake Torneträsk in 1912 and 2009. The yellow lines denote the 30\%-tree-cover isolines (statistically determined by using the software ArcGIS Spatial Analyst 9.2). The process of identifying the elevational position of this isoline in the old photographs is illustrated here: in the centre of the inset, a rock outcrop attached to the bedrock can be seen that was positioned near the upper limit of the isoline of 1912. The same landmark is seen on the 2009 photograph and could be recorded in the field with a GPS-device with an aneroid altimeter. As a reference, elevation in metres above sea level is indicated. Upper photo: B. Mesch, lower photo: R. Van Bogaert.

Fig. 3. Repeat aerial photograph analysis on Mount Nuolja in sub-Arctic Sweden. Contrasting tree line dynamics are seen for the east- and south-facing slope for the period 1959-2000. The statistically-determined 30\%-tree cover isoline is plotted in yellow. Note that due to different camera filters, trees are plotted as white dots in the images on the left, but rather as dark reddish dots on the infrared-images on the right.

Fig. 4. The tree line ecotone near transect N1 on the northern side of Lake Torneträsk in 1952 and 2009. The statistically-determined 30\%-tree cover isoline is plotted in 
yellow. Although the 2009 photograph is taken in winter causing a reduced treecover, large forest gaps are seen as a result of a severe moth outbreak in 1964-1965. Upper photo: E. Persson, lower photo: S. Johnsson.

Fig. 5. Comparison of the tree line transects N1, N2, and S1 visited in 1977 and 2006. The colours of the bars represent different d.b.h. or age classes. Black bars denote birch trees that established before 1900, dark grey bars birches with a d.b.h. $>7.5 \mathrm{~cm}$ that established after 1900, light grey bars birches with a d.b.h. between 2.5 and 7.5 $\mathrm{cm}$, and white bars birch saplings with a d.b.h. $<2.5 \mathrm{~cm}$. Note the different scaling of the vertical axis of site S1. (NB: the gap between c. 520 and $640 \mathrm{~m}$ a.s.l. at site N1 is due to forest defoliation by invertebrates, see Fig. 4.)

Fig. 6. Orographic tree line sites with an inclination $>35^{\circ}$ showed long-term stability. The statistically-determined $30 \%$-tree cover isoline is plotted in yellow. Upper photo on the left: E. Persson, bottom left: B. Mesch; upper and bottom right: R. Van Bogaert.

Fig. 7. Estimated annual birch recruitment at the tree line of Mount Nuolja (a) in relation to disturbance (b) and summer temperature (c) for the period 1964-2006. Note that birch-minus-pine indices were plotted as such that positive values point to increased moth damage. See text for correlations.

Fig. 8. Tree ( $>2 \mathrm{~m}$ ) establishment at the Torneträsk tree line versus summer (JuneAugust) temperature and reindeer population numbers for the period 1800-2000. A second-degree polynomial function shows the long-term summer temperature trend. 
Presumed annual tree establishment numbers were grouped into 10-year classes for five tree line sites: the east and south slope of Mount Nuolja $\left(\mathrm{M}_{\mathrm{S} 3}\right)$, and the transect areas N1, N2, and S1 (Fig. 1). Reindeer population numbers for the Torneträsk area were split up into intensively managed reindeer (thick solid red line) that were kept near the tree line, and extensively managed reindeer (thin solid orange line) that wander freely (after Emanuelsson, 1987). See text for correlations. 


\section{Figures}

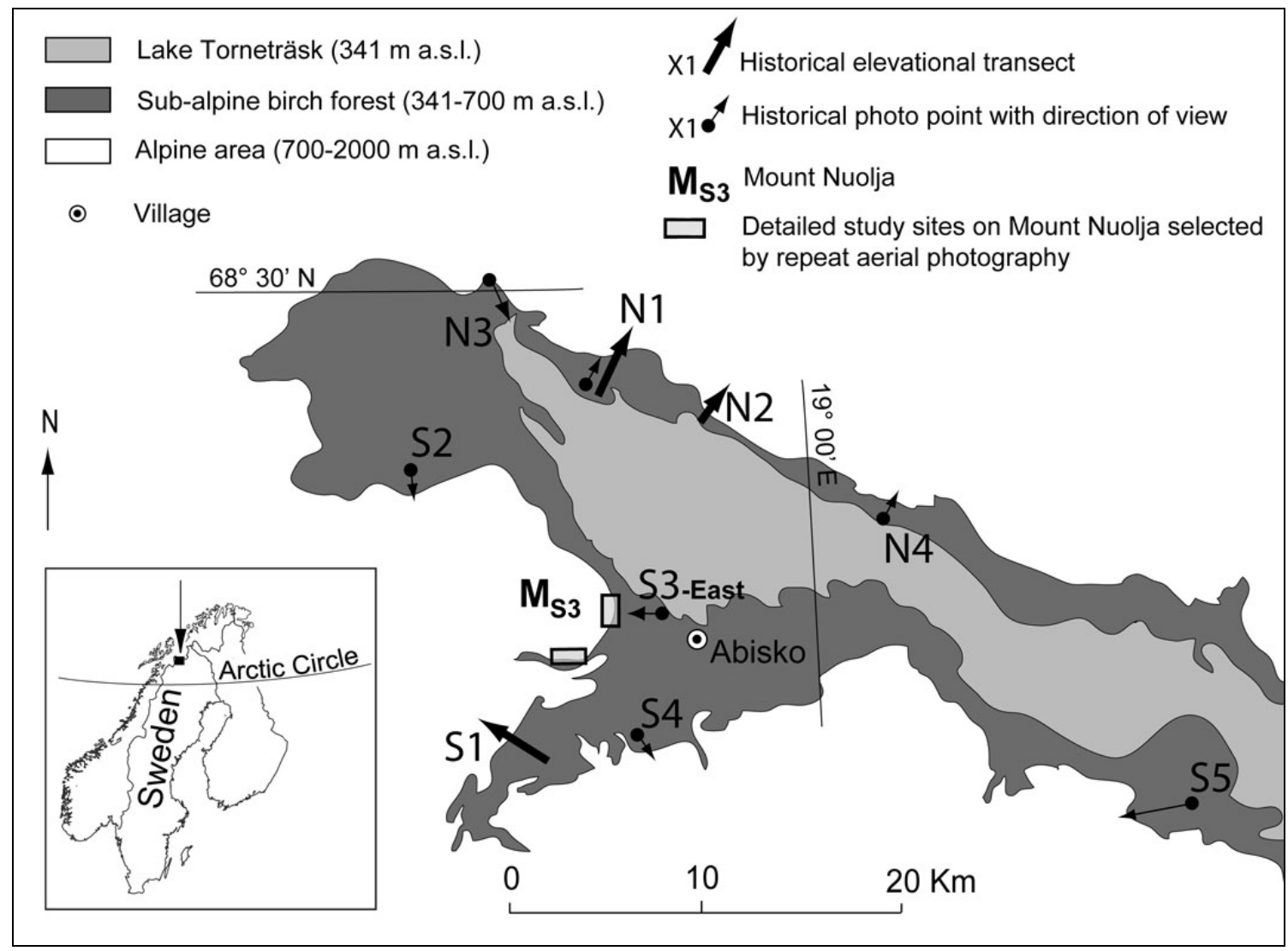

Fig. 1. The Torneträsk study area in sub-Arctic Sweden. The locations of the historical transects and photo points that have been revisited to study changes in the tree line ecotone are indicated. 

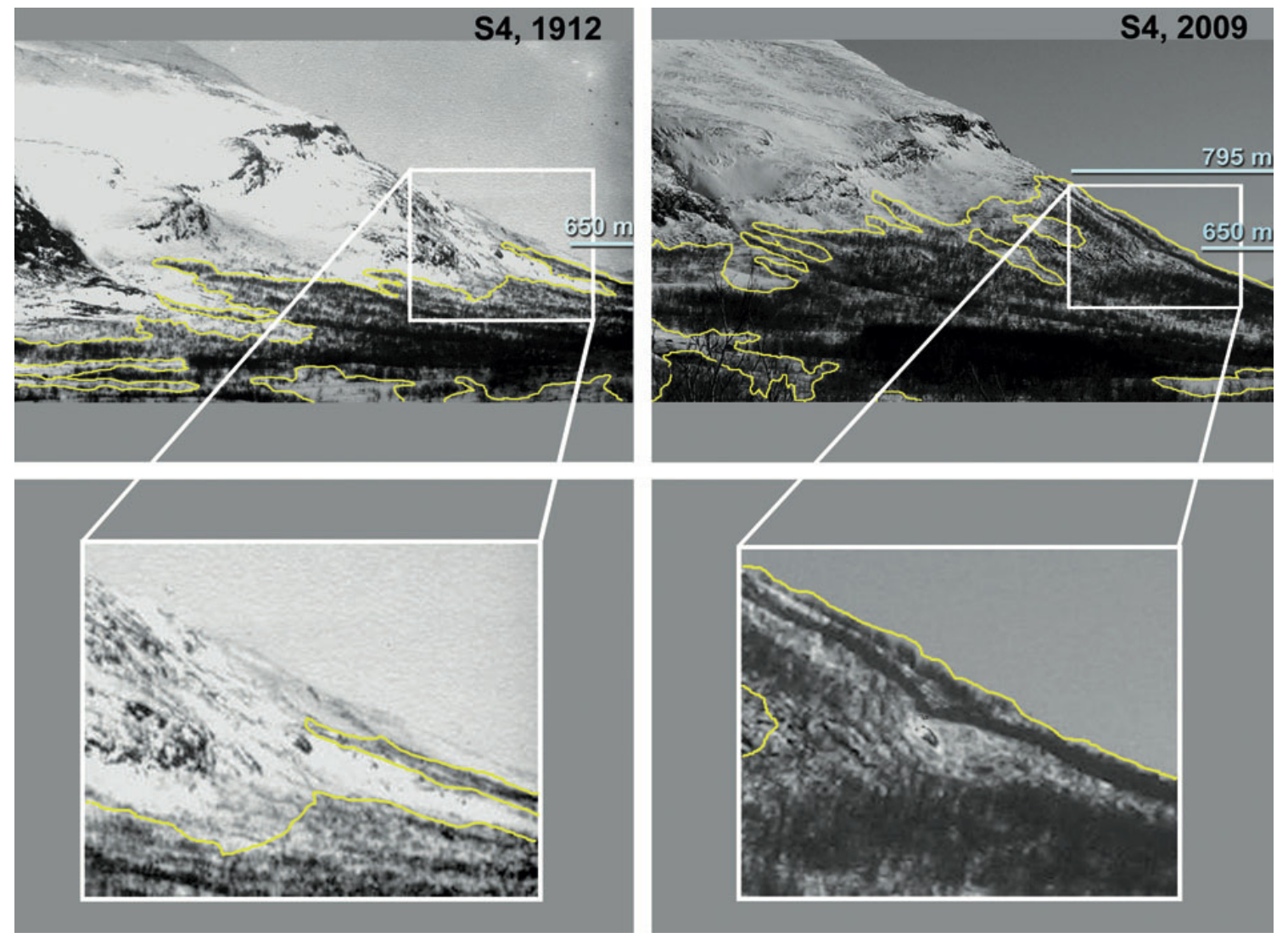

Fig. 2. Tree line site S4 on the south side of Lake Torneträsk in 1912 and 2009. The yellow lines denote the $30 \%$ tree-cover isolines (statistically determined by using the software ArcGIS Spatial Analyst 9.2). The process of identifying the elevational position of this isoline in the old photographs is illustrated here: in the centre of the inset, a rock outcrop attached to the bedrock can be seen that was positioned near the upper limit of the isoline of 1912. The same landmark is seen on the 2009 photograph and could be recorded in the field with a GPS-device with an aneroid altimeter. As a reference, elevation in metres above sea level is indicated. Upper photo: B. Mesch, lower photo: R. Van Bogaert. 

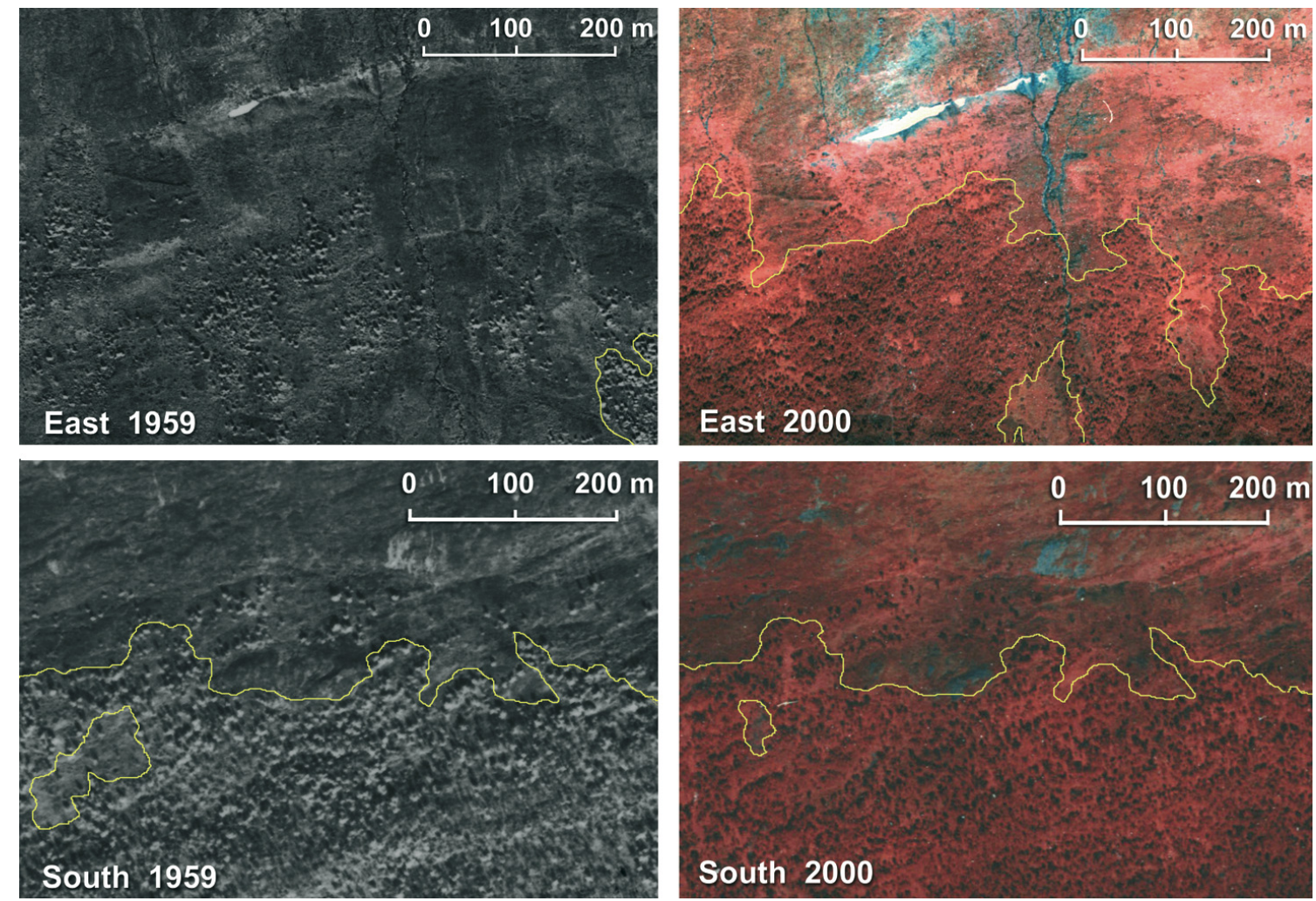

Fig. 3. Repeat aerial photograph analysis on Mount Nuolja in sub-Arctic Sweden.

Contrasting tree line dynamics are seen for the east- and south-facing slope for the period 1959-2000. The statistically-determined $30 \%$ tree-cover isoline is plotted in yellow. Note that due to different camera filters, trees are plotted as white dots in the images on the left, but rather as dark reddish dots on the infrared-images on the right. 

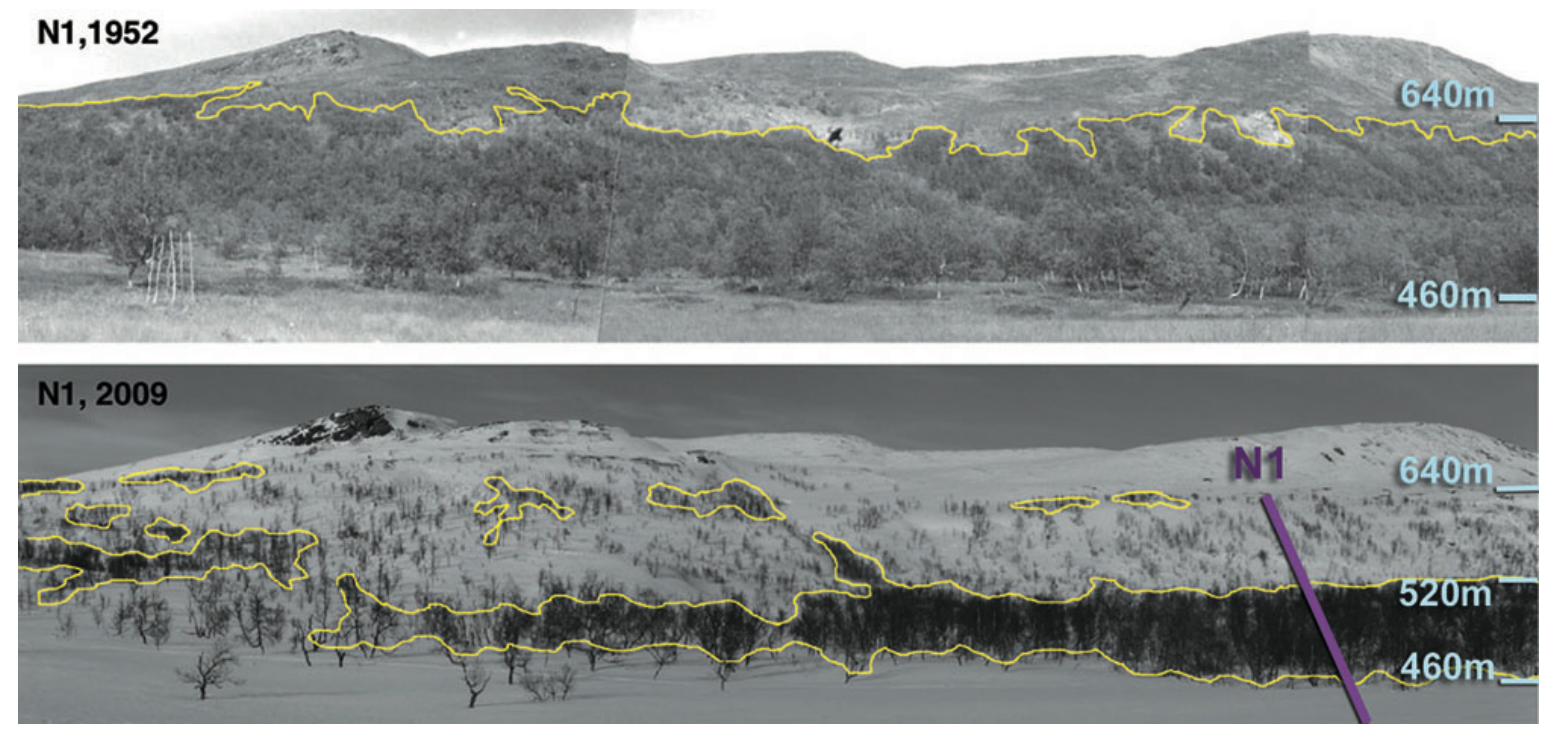

Fig. 4. The tree line ecotone near transect N1 on the northern side of Lake Torneträsk in 1952 and 2009. The statistically-determined 30\% tree-cover isoline is plotted in yellow. Although the 2009 photograph is taken in winter causing a reduced treecover, large forest gaps are seen as a result of a severe moth outbreak in 1964-1965. Upper photo: E. Persson, lower photo: S. Johnsson. 

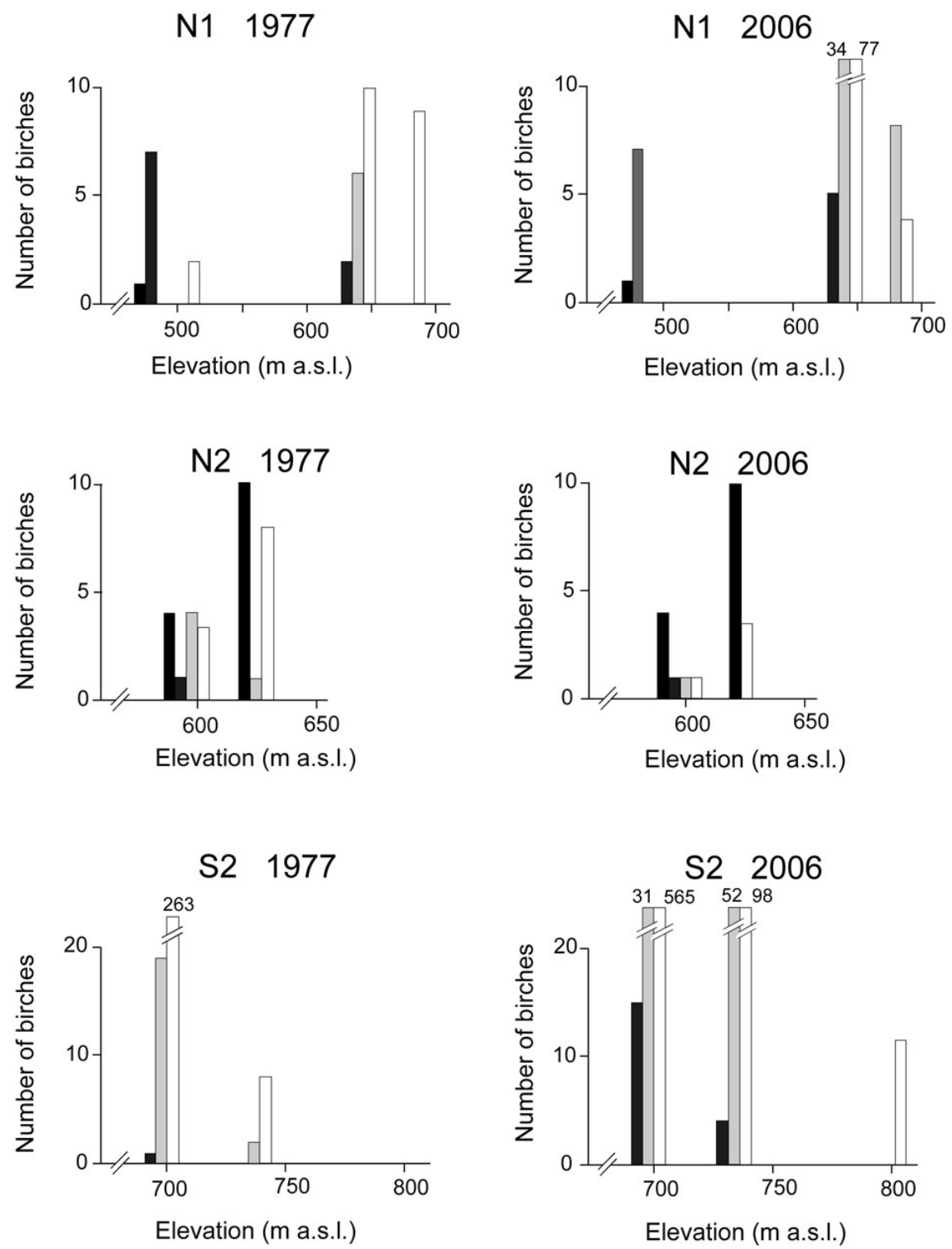

Fig. 5. Comparison of the tree line transects N1, N2, and S1 visited in 1977 and 2006. The colours of the bars represent different d.b.h. or age classes. Black bars denote birch trees that established before 1900, dark grey bars birches with a d.b.h. $>7.5 \mathrm{~cm}$ that established after 1900, light grey bars birches with a d.b.h. between 2.5 and 7.5 $\mathrm{cm}$, and white bars birch saplings with a d.b.h. $<2.5 \mathrm{~cm}$. Note the different scaling of the vertical axis of site $\mathrm{S} 1$. (NB: the gap between c. 520 and $640 \mathrm{~m}$ a.s.l. at site N1 is due to forest defoliation by invertebrates, see Fig. 4.) 

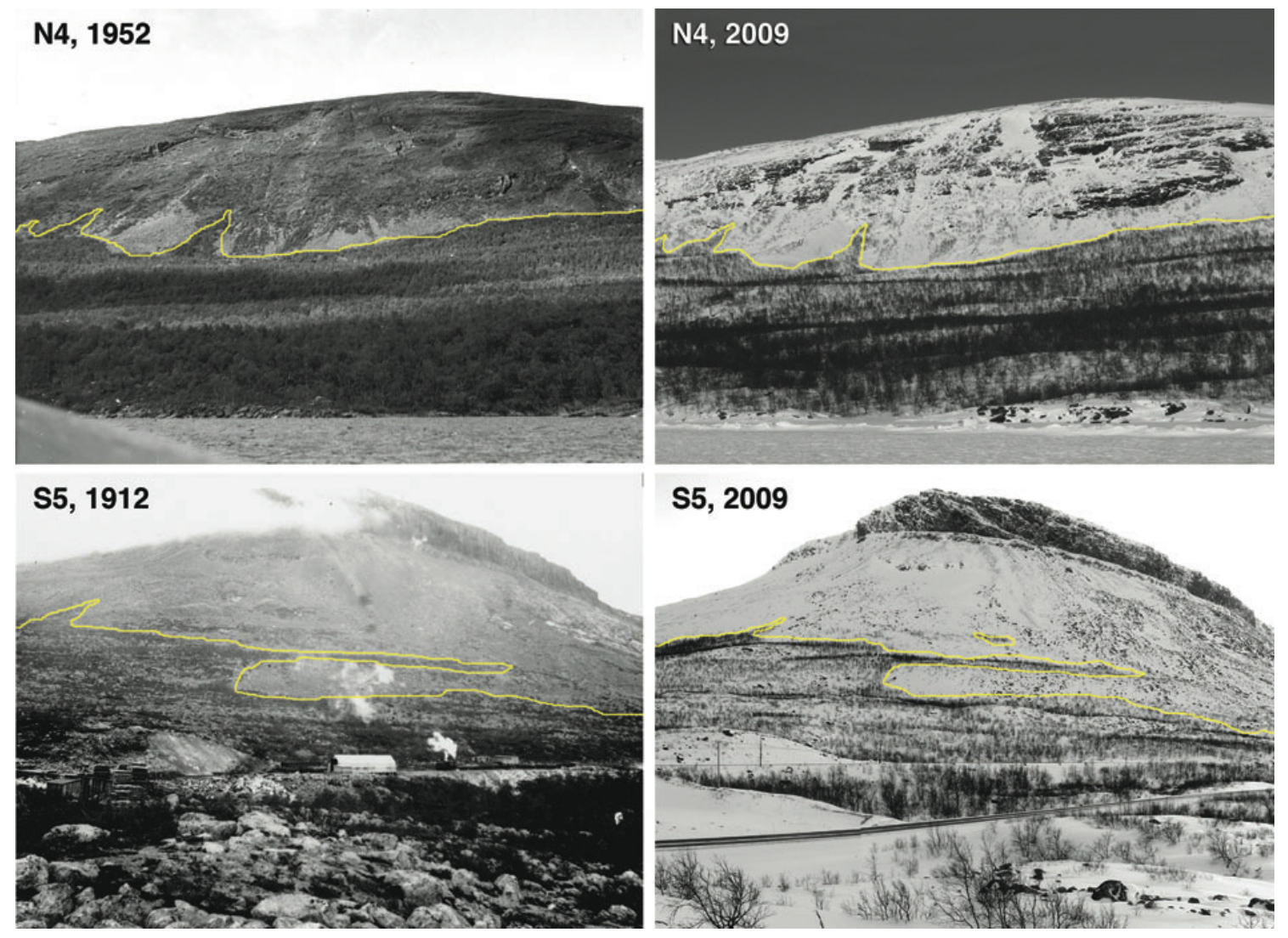

Fig. 6. Orographic tree line sites with an inclination $>35^{\circ}$ showed long-term stability.

The statistically-determined $30 \%$ tree-cover isoline is plotted in yellow. Upper photo on the left: E. Persson, bottom left: B. Mesch; upper and bottom right: R. Van Bogaert. 

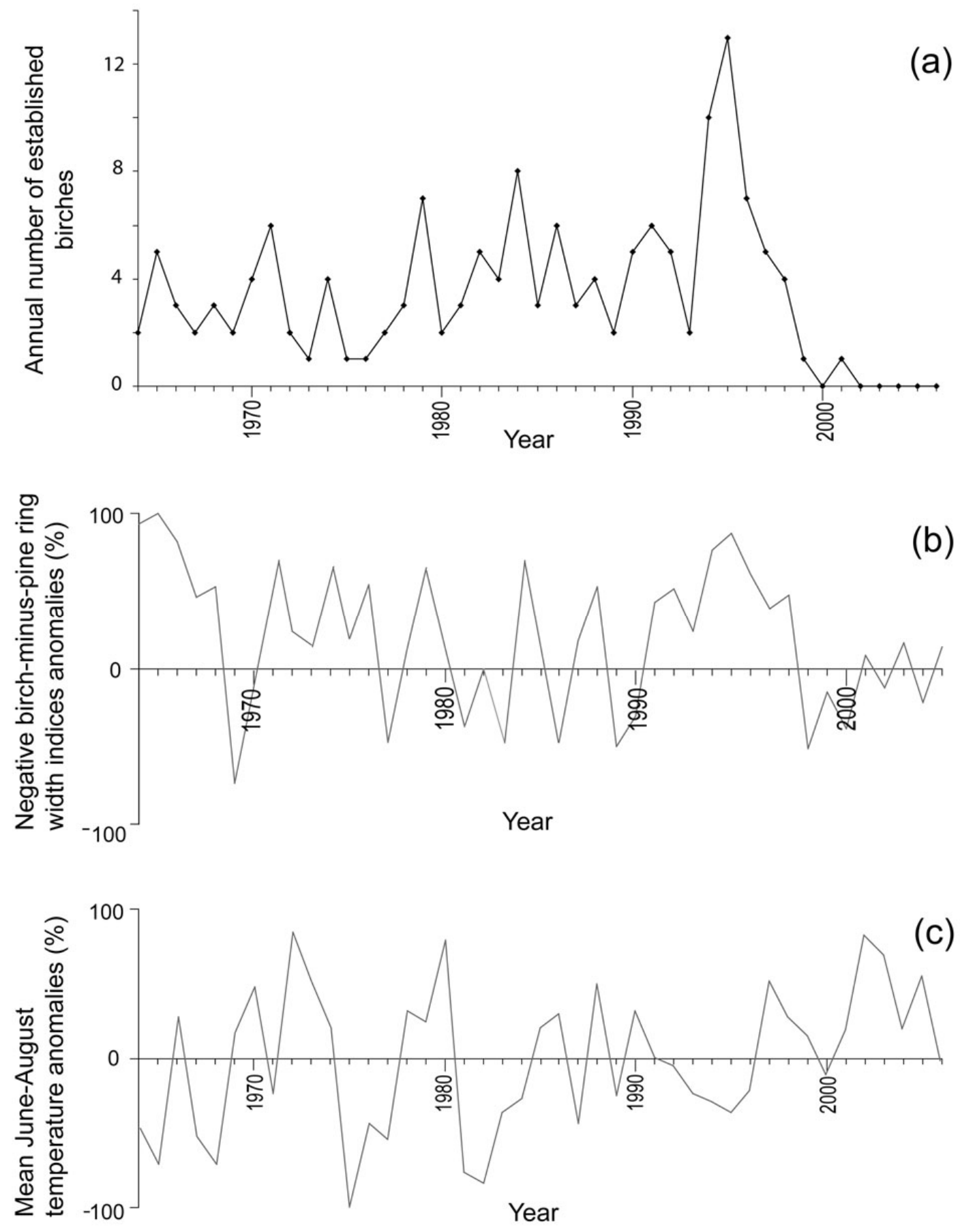

Fig. 7. Estimated annual birch recruitment at the tree line of Mount Nuolja (a) in relation to disturbance (b) and summer temperature (c) for the period 1964-2006. Note that birch-minus-pine indices were plotted as such that positive values point to increased moth damage. See text for correlations. 


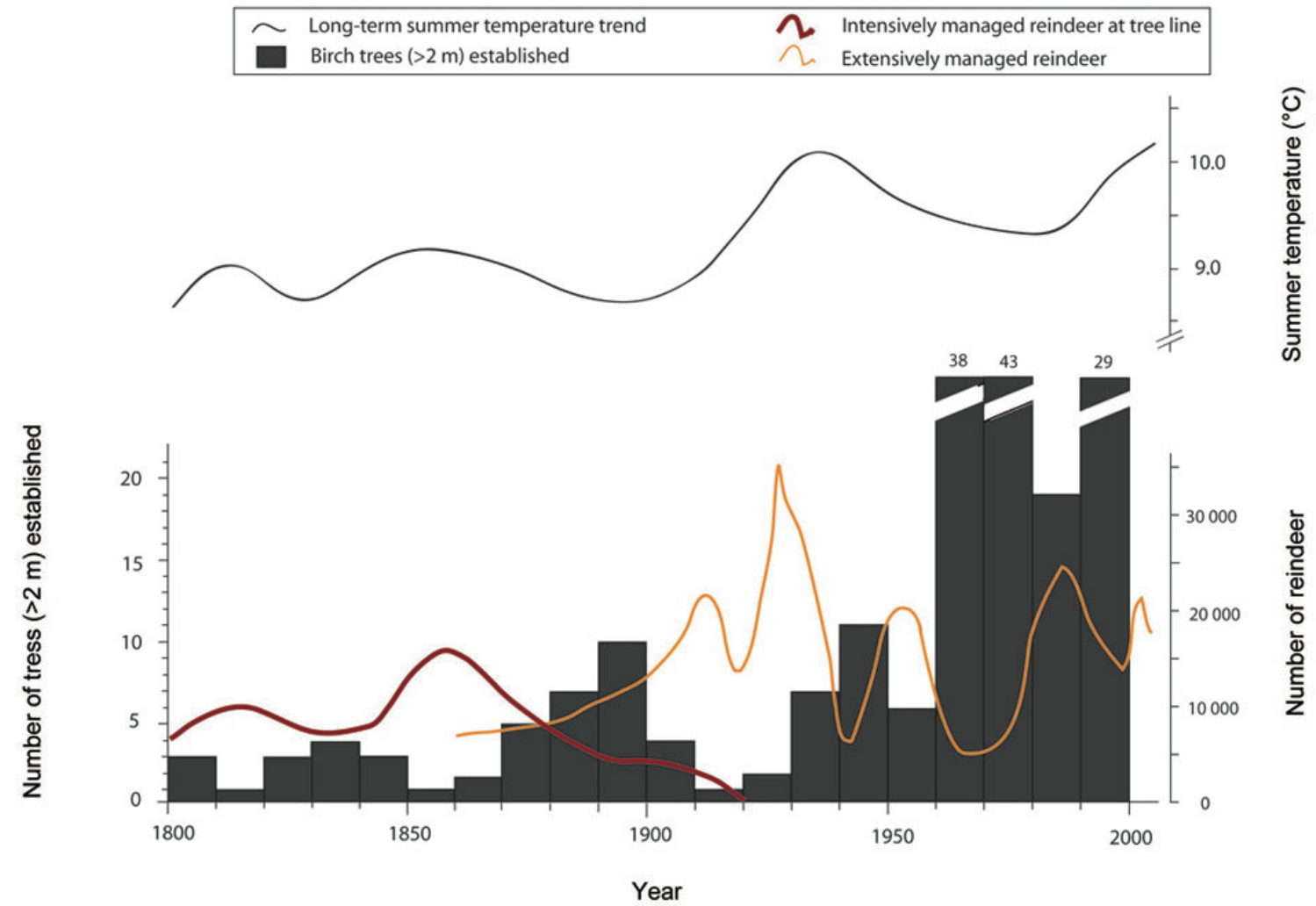

Fig. 8. Tree $(>2 \mathrm{~m})$ establishment at the Torneträsk tree line versus summer (JuneAugust) temperature and reindeer population numbers for the period 1800-2000. A second-degree polynomial function shows the long-term summer temperature trend. Presumed annual tree establishment numbers were grouped into 10-year classes for five tree line sites: the east and south slope of Mount Nuolja $\left(\mathrm{M}_{\mathrm{S} 3}\right)$, and the transect areas N1, N2, and S1 (Fig. 1). Reindeer population numbers for the Torneträsk area were split up into intensively managed reindeer (thick solid red line) that were kept near the tree line, and extensively managed reindeer (thin solid orange line) that wander freely (after Emanuelsson, 1987). See text for correlations. 